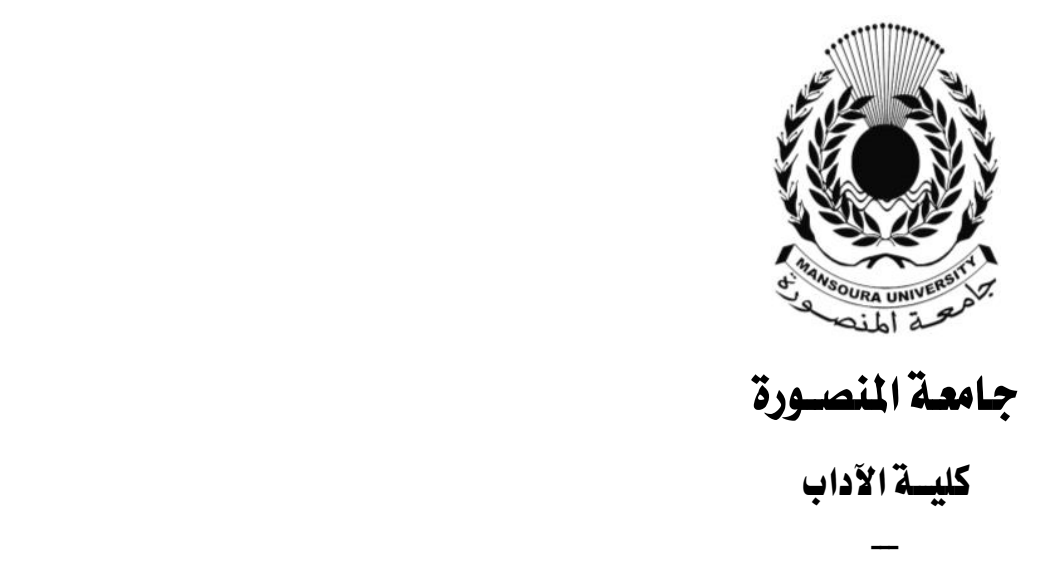

السرد القصصي في شعر الغزال

إعـــداد

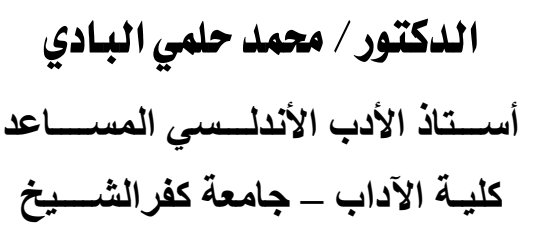

مجـلة كلــية الآداب - جـامعــة المنصــورة

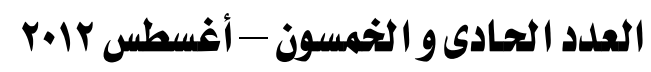




\section{السرد القصصي في شعر الغزال}

\section{د. - محمد حلمي البادي}

\section{مقدمـة - مقة}

الحمد لله رب العالمين، والصلاة والسلام على المبعوث رحمة للعالمين، سيدنا محم، عليه وعلى آله وصحبه أجمعين، وبعد ...

فقد لفت نظري، وأثار انتباهي، وأنا أقرأ كتاب محمد صالح البنداق (( يحيي بن

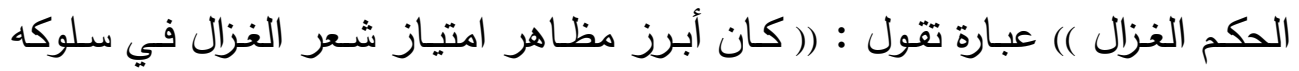

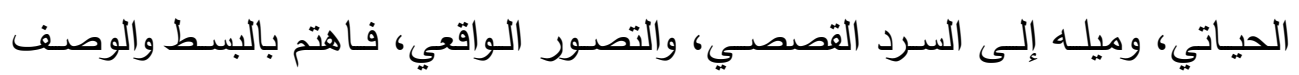

والتحليل، فجاء شعره هينا لينا عليه ميزة الفن القصصي والعميق في آن واحد )('). ومنذ هذه اللحظة وأنا عازم على دراسة هذا الجانب المهح في شعر الغزال، وهو السرد القصصي، خاصة أن أكثر من باحث(؟) قد أشار إليه، وإلى اهتمام الغزال

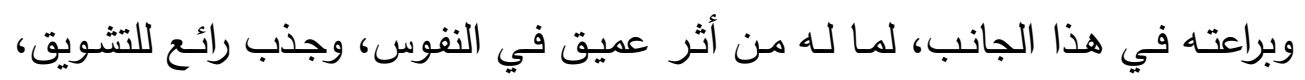
وجوانب متعددة للعظة والاعتبار .

ومن الدراسات السابقة أيضا دراسة للباحث أسامة اختيار بعنوان"بنية المشهد

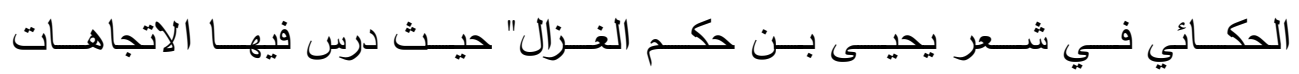

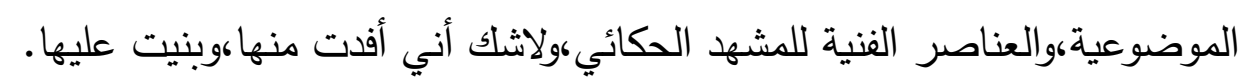
يعدُ الغزال أول شعراء الأندلس (107 ـ 100 بهــ) اهتماماً بالفن القصصي

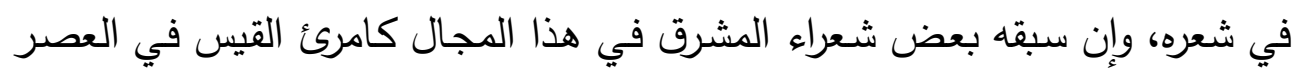

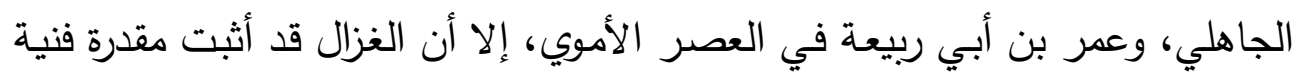
رائعة، بل وبذهم جميعاً، وتفوق عليهم في هذا الفن. 


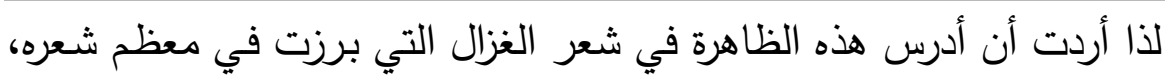

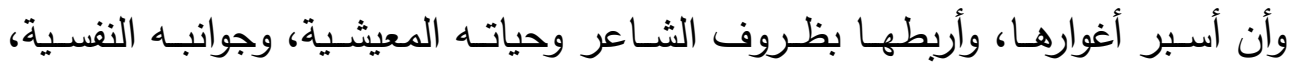
ومواقفه من الحياة، وخلاصة تجاربه، وميله الثديد إلى هذا الفن. وبناءً عليه كان لزاماً على الباحث أن يطرق هذا الجانب في شعر الغزال في

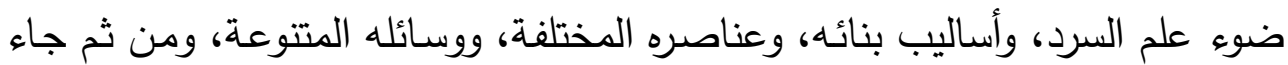
البحث في مقدمة وتمهيد ومبحثين وخاتمة.

أمسا المقدمة التي بين أيدينا فقد تعرفنا فيها على موضوع البحث، وسبب

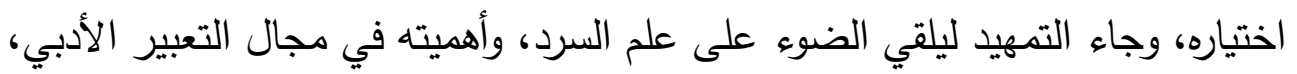

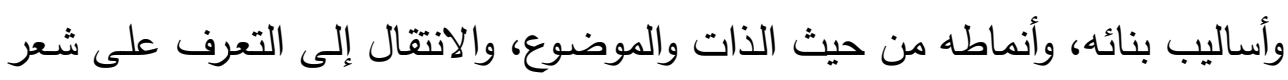

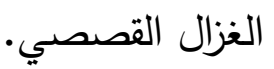

ثم جاء المبحث الأول بعنوان (( عناصر السرد )) ومنها، الحدث والشخصية

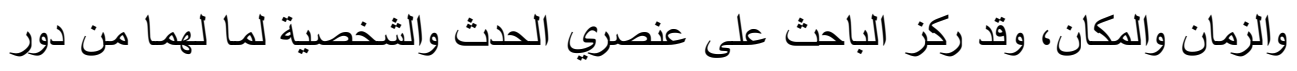
كبير في الفن القصصي، وغض الطرف عن عنصري الزمان والمكان لعدم إثرائهما هذا الفن خاصة القصص الثعري عند الغزال. وتتـاول المبحث الثاني (( وسائل السرد )) الحوار والوصف باعتبارهما أهم

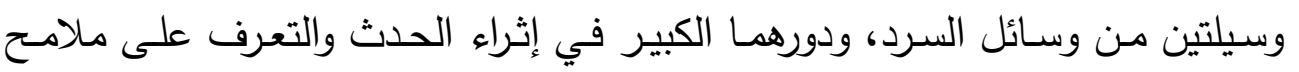

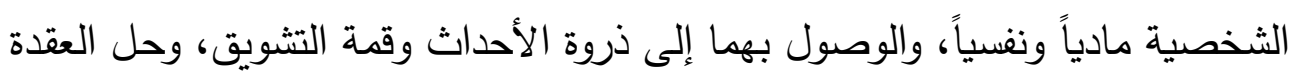
في نهاية القصة. وأخيراً جاءت الخاتمة لترصد أهم النقاط التي توصل إليها الباحث من خلال موضوع البحث.

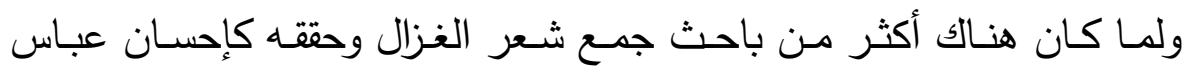
وصالح البنداق ورضوان الداية وعلي الغريب الثناوي فقد رأيت أن أعتمد في دراستي 
على آخر نشرة قام بها الدكتور علي الغريب وهي"شعر يحيى بن حكم الغزال،جمع وتحقيق ودراسة" وذلك لما تتمتع به من استيعاب لكل النشرات السابقة،بالإضـافة إلى النصوص الثـعرية الجديدة التي أضـافها المحقق من السفر الثاني لكتاب "المقتبس" لابل

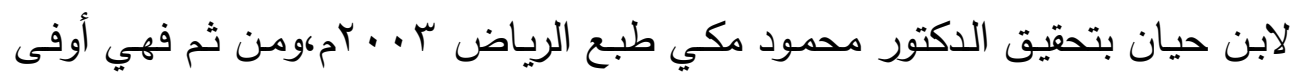

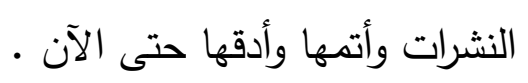




\section{التمهيــد}

يتناول هذا التمهيد جانبين متعلقين بخط سير البحث؛ الأول يلقي الضوء على السرد وتعريفه، وأساليب بنائه، وأنماطه. والثاني يستكثف فن الغزال القصصي، وأهم القضايا والمواقف المتعلقة بهذا الفن.

أما السرد فهو (( الطريقة التي تحكي بها قصة، وتسمى هذه الطريقة سردا، فالسرد هو الذي يعتمد عليه في تمييز أنماط الحكي بشكل أساسي )(ז). فالشـاعر ينقـل بطريقـة السـرد مواقف عمله القصصـي، وتتشـكل مـن خلالـه العناصـر الفنيـة

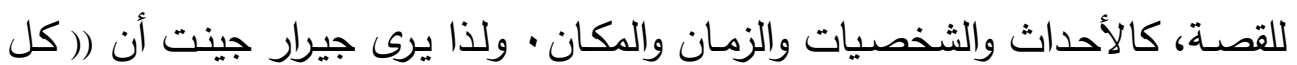
عمل سردي يحتوي صوراً من الحركات والأحداث، وهذه الصور هي التي تشكل السرد بمفهومـهـ الـدقيق، كمـا أن كـل عمـل سـردي يشـتمل على صــور مـن الأشــياء والشخصيات، وهي التي تمثل في العهد الراهن ما يطلق عليه الوصف، وذلك على الرغم من أن هذه الصور شديدة الامتزاج عميقتها، دقيقتها، ممتدة على مدى العمل

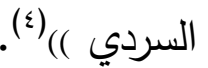

ويذهب عبد الملك مرتاض إلى أن أصل السرد في اللغة العربية هو التتابع الماضـي على وتيرة واحدة، وسـرد الحديث والقراءة مـن هذا المنطلق الاشتقاقي، ثم

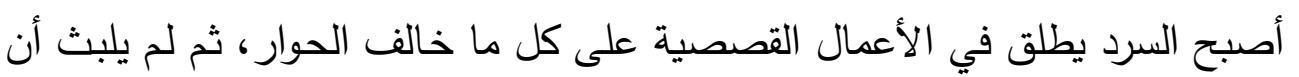
تطور مفهوم السرد إلى معنى اصطلاحي أهم وأشمل بحيث أصبح يطلق على النص

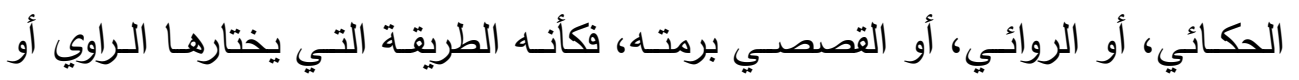
القاص، أو حتى المبدع الشعبي ليقدم بها الحدث إلى المتلقي، فكأن السرد إذن نسيج

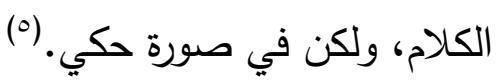
والسـرد في مجـال التعبير الأدبي " عرض لحدث أو لمتواليـة من الأحداث حقيقية أو خيالية ، عرض بوساطة اللغة ، وبصفة خاصة لغة مكتوبة"(T) . 
وعلى هذا فإن البنية السردية في أي خطاب شعري لابد وأن تتبع من وجود عناصر السرد والحكي في هذا الخطاب ، ذللك أن الشاعر في طرحه الانفعالي يقص قصة بشخوصها وأحداثها وما يتعلق بها من زمن سردي ومكان وحبكة ثم انفراج تلك

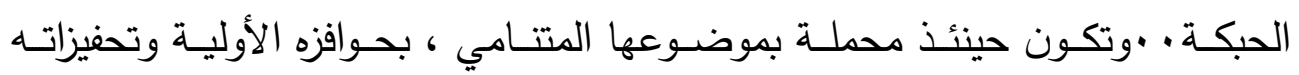
التشكيلية برؤية سردية من التبئير إلى العوامل في علاقاتها المتعددة •(V) كما أن البنية السردية مستقلة تمام الاستقلال في وظيفتها المتمثلة في كونها "تركب وتعيد التركيب ، وتبدع ، وتعيد تأسيس سلسلة متكاملة ومتداخلة من الوقائع

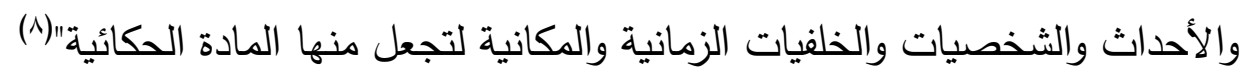
أمسا أسـاليب بناء السرد أو أنماطه فقد حدد (( توماشفسكي )) نمطين رئيسين للحكي : سرد موضوعي وسرد ذاتي، فالأول يطلع فيه الكاتب على كل شيء يخص الأبطال، ولكنه غائب عن القصة التي يرويها، والثاني سارد حاضر · ويسمى جينت النمط الأول غيري القصة، والنمط الآخر مثلي القصة(9). وبناء على ما طرحه جينت من أنماط، فإن النمط الثاني الذي أطلق عليه مثلى القصة يمكن أن يكون السارد فيه بطل حكايته، ومن الجائز أن يلعب فيها دوراً

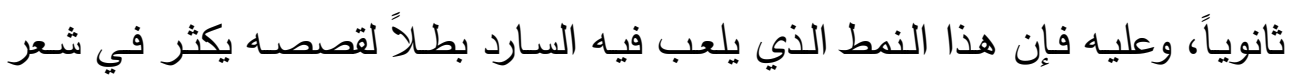
الغزال، لأنه يريد أن يلعب دور البطولة في كثير من حكاياته وأشعاره القصصية لما يتمتع به من خبرة كبيرة وسخرية لاذعة ودعابة مرحة.

إذن (( فكل بناء سردي هو ذاتي بالضرورة في المستويين السطحي والعميق، وكل ذات ينطلق من موقع، وكل موقع يقتضي موقفاً من الوجود بأنساق فنية، يتجلى

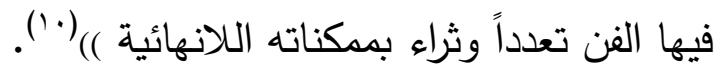
أما الفن القصصي فهو فن قديم لله جاذبيتة وعشاقه، والقصة - قديماً - كما يعرفها قاموس (لاروس) : (( حكاية حقيقية أو مصطنعة منظومة أو منثورة، مصبوبة 
في قالب قصصي )(')". أما حديثاً فيعرفها تشـارلتون بأنها : (( ضـرب من الخيال

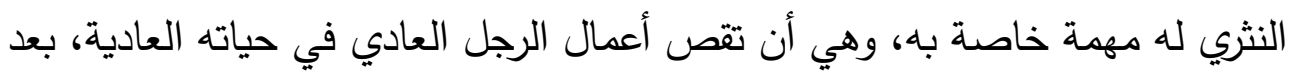

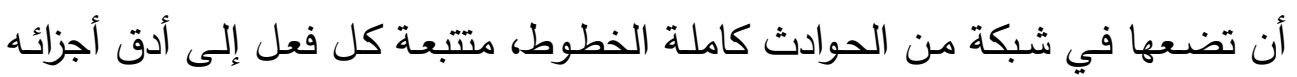

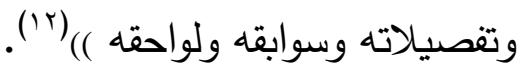

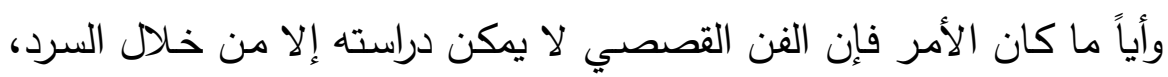

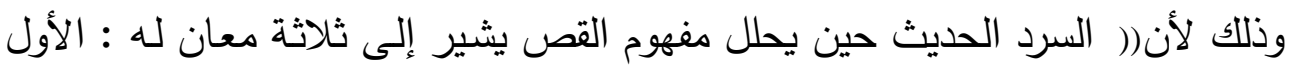

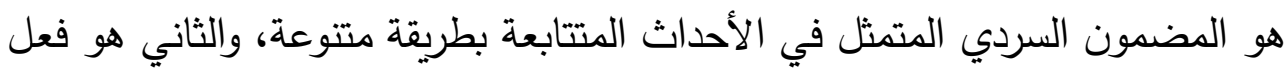

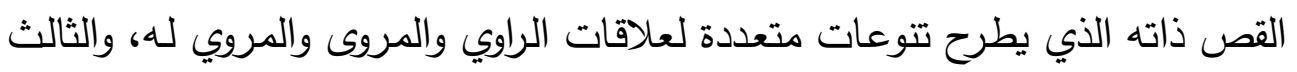

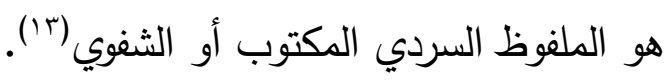
والفن القصصي الشعري عند الغزال يستوعب كثيراً من آليات السرد المختلفة،

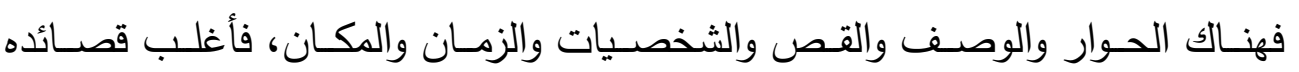

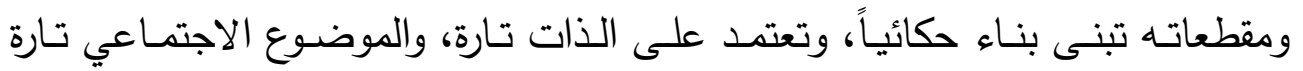

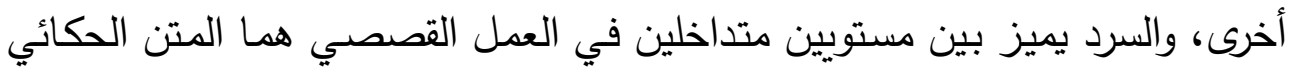

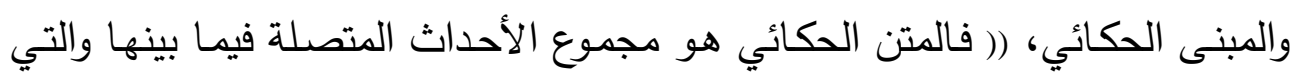

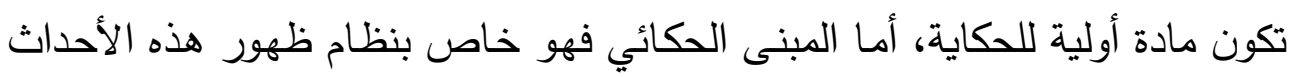

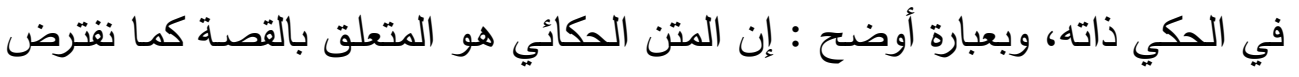

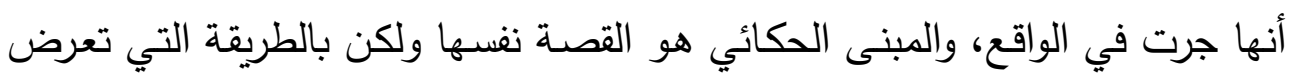

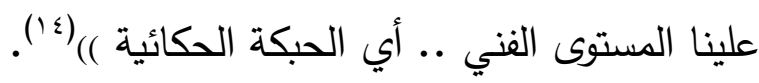
وقد أشار تودروف إلى أن كل مستوى من المستويين السابقين (المتن الحكائي

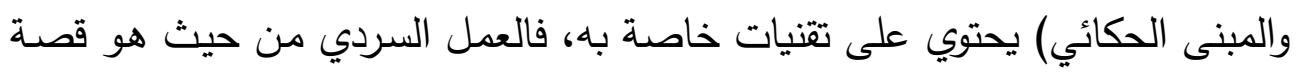

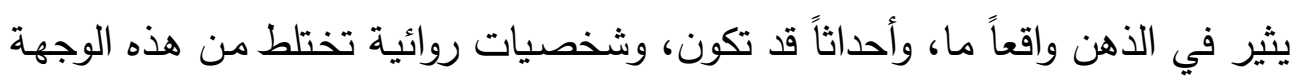

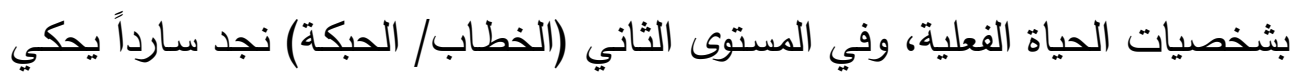
هذه القصة ، كما يوجد قارئ يدركه(1). 


\section{المبحث الأول}

عناصر السرد القصصي

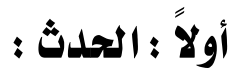

يتطلب أي عمل سردي قصصسي رد هذا العمل إلى الثنائية التي أثـار إليها

الشكلانيون الروس، وهي المتن الحكائي والمبنى الحكائي، أو الحكاية والخطاب، أو الخبر والسرد، أو القصـة والحبكة، فالمتن الحكائي يعني مجموع الأحداث المتصلة فيما بينها والتي تكون مـادة أولية للحكاية، وأمـا المبنى الحكائي فهو خاص بنظسام ظهور هذه الأحداث في الحكي ذاته، وبعبارة أوضـح: إن المتن الحكائي هو المتعلق بالقصـة كما يفترض أنها جرت في الواقع، والمتن الحكائي هو القصـة نفسها، ولكن

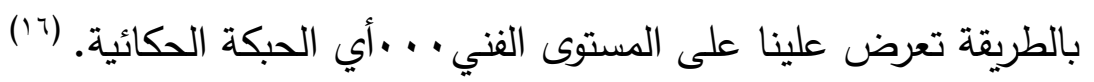
والسرد بمفهومه الحديث يقوم على ثلاثة محاور في تحليله للقصة:يتتاول الأول المضـمون السـردي المتمثل في الأحـداث المتتابعـة بطريقـة متتوعـة،والمحور الثاني يتعلق بفعل القص ذاته،وأما المحور الثالث فهو الملفوظ السردي المكتوب أو الشفوي.

فالحدث في العمل الشعري القصصي يقوم على إحدى طريقتين؛ الطريقة

الأولى يكون فيها الحدث ذا موضوع واحد محدد، وله زمان ومكان محددان، والطريقة الثانية يتفرع فيها الحدث إلى حدث رئيس وآخر نوعي ثانوي وما أحرانا هنا أن نستدعي كلام ابن رشيق في إشاراته السردية في النص الشعري الحكائي إذ يقول:" ومن النـاس من يستحسن الثـعر مبنيـا بعضـه على بعض، وأنـا أستحسن أن يكون كل بيت قائما بنفسه لا يحتاج إلى ما قبله، ولا إلى ما بعده ، وما سوى ذللك فهو عندي تقصير ، إلا في مواضع معروفة مثل الحكايات وما شاكلها ،

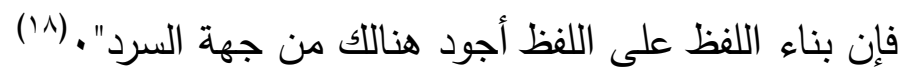


نلاحظ على مقولة ابن رشيق أنه جعل السرد الثعري قائما على: احتياج البيت

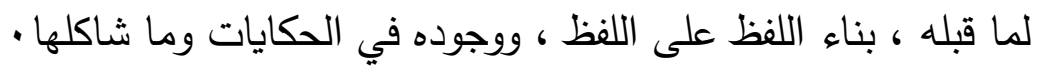
وبناء الحدث في الرواية يختلف عن بناء الحدث في العمل الثعري القصصي،

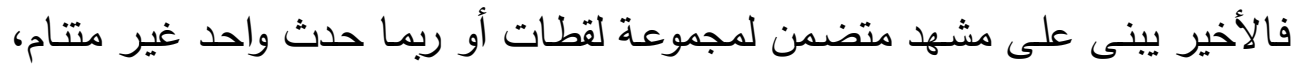

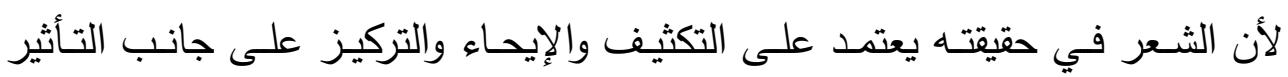

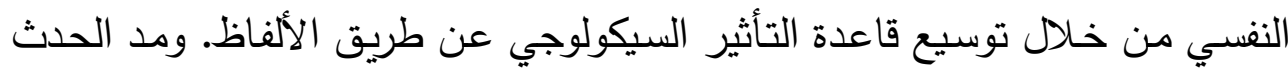
على مساحة شعورية، وليس على مساحة نصية أو حركية كما نرى في البناء الروائي والقصصي(19).

يعبر الغزال في كثير من قصصه الثعرية عن مواقف وقضايا من أحداث

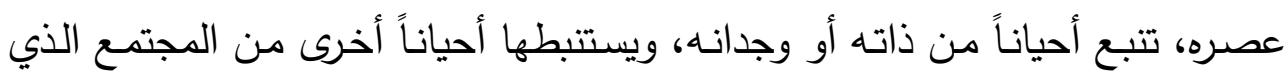

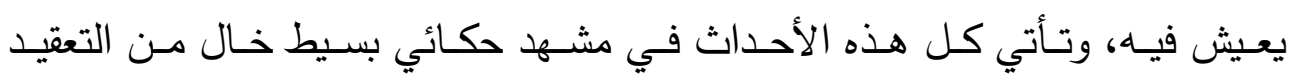

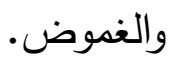

ولعل أول هذه الأحداث التي صورها الغزال في مشهـ قصصي رائع توفرت

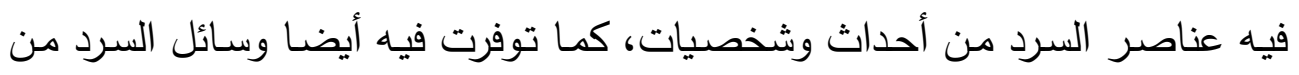

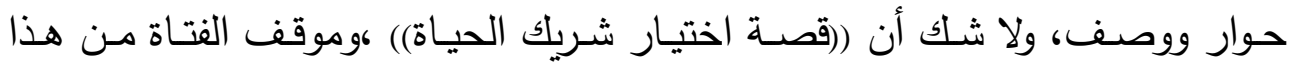
الاختيار من القصص الاجتماعية التي تصلح لكل زمان ومكان، وقد حكاها الغزال في أسلوب سردي حواري بين الفتاة وأبيها(·r) :

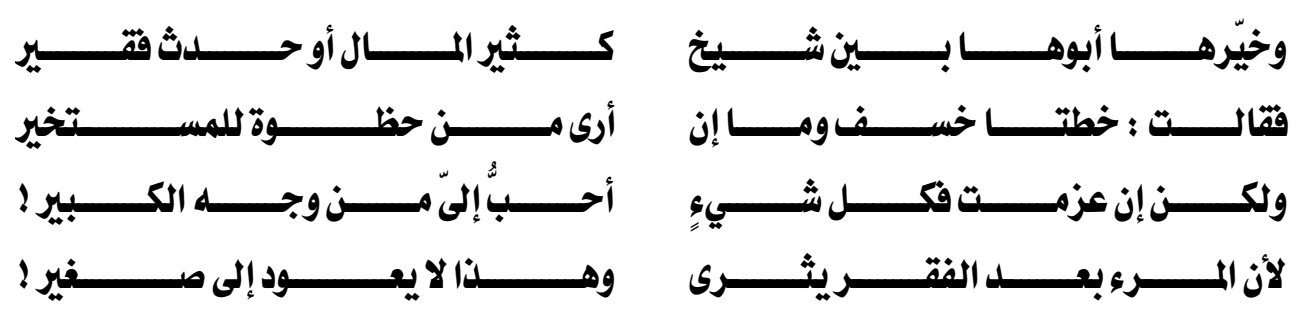


فالحدث بسيط يقوم على موضوع واحد محدد، بناه الغزال من واقع الحياة

اليومية،وقد سرده من خـلال حوار دار بين الفتاة وأبيها وهو" اختيار شريك الحياة"، فهنالك في كثير من المجتمعات من نجده يرغم ابنته على الزواج من عجوز غني، والعزوف عن الثاب الفقير ، وهنا تقف الفتاة حائرة بين اختيار أبيها ورغبتها الحقيقية، فالغزال يسـوق المشـهـ عن طريق الحوار المفعم بالأسـى والحزن بين الفتاة وأبيها.

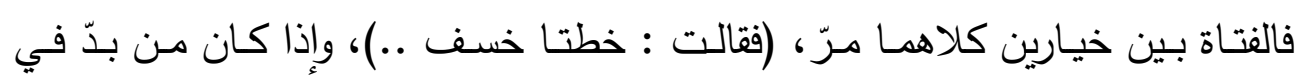
الاختيار (ولكن إن عزمت ..) فإنها تختار الشاب الفقير الذي اختاره لها الشاعر بعد أن تبنى موقفها، ومن ثم (( فالثـعر عند الغزال تعبير عن موقف أو رأي يقال، أو أو

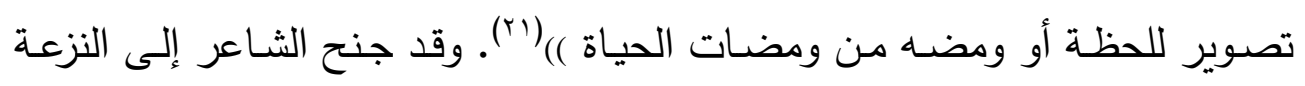
التعليلية، فالفقير قد يثرى، ولكن العجوز لا يعود إلى صغير ، وهنا نرى الغزال يميل إلى التحليل في تصوير حيرة الفتاة.

ونلاحظ في هذه الأبيات اشتمالها على بذور قوية لمفهوم السرد الحكائي التي

تتوفر فيها عناصره وهي : الراوي ( السارد) وهو الشـاعر نفسـه، الحدث (الفعل) وهو تخيير الفتاة بين عرضين للزواج ،و الشخصيات المتحدثة (الشاعر - الأب - الفتاة). كما نلاحظ أن الراوي (السارد) وهو الثاعر نفسه اتخذ لنفسه شكلا من أشكال الروي وهو الثاهد الحاضر للحدث دون تدخل رغم علمه بمضمون هذا الحدث، حيث يصف ويسـرد ويستخلص الحكمـة.تقول د •يمنى العبد:" يمكن أن يكون الراوي هو البطل يحكي قصته فيحلل ويسقط المسافة بينه وبين مـا يروي ، ويمكن أن يكون

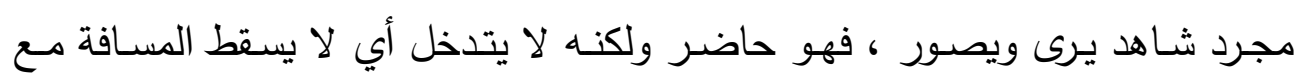

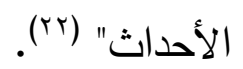
وإذا كان الغزال قد وقف بجانب الفتاة الثـابة في القصـة السابقة لأنه اتخذ دور المصلح الاجتماعي، وله رؤية شعرية، ونزعة عقلية تعليلية، فإنه في الحكاية التالية يختلف في موقفه ورؤيته حيث يعرض لنا متصـابياً آخر مسناً وبجانبه فتاة صغيرة 
السن، وعن طريق الحوار الذي دار بين الثيخ والثاعر يفهم أن الثيخ قد وصل إلى الى الثل

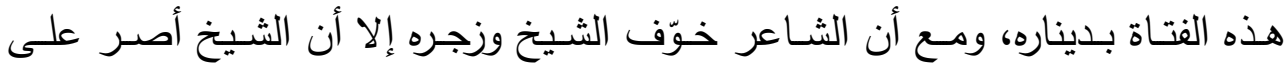

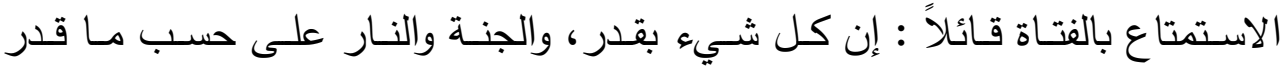
للإنسان (rr)

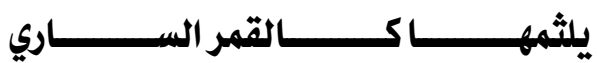

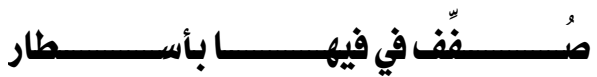

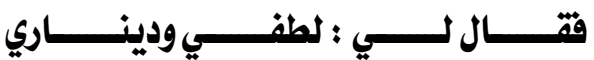

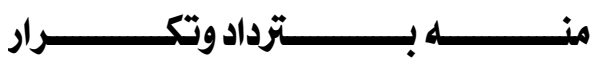

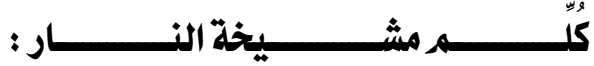

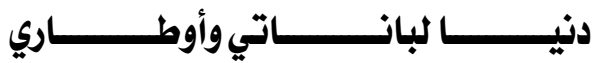

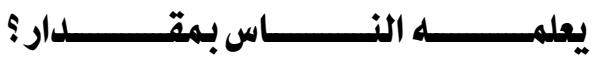

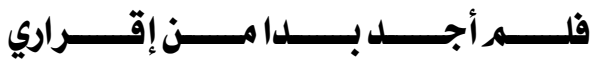

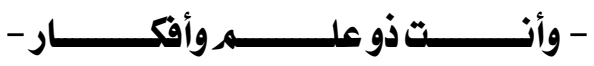

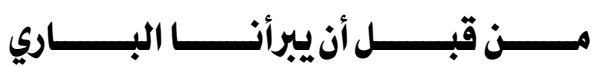

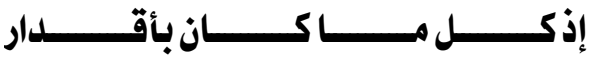

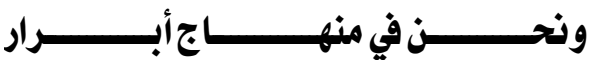

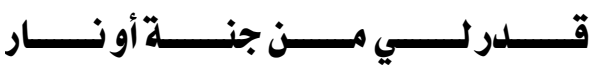
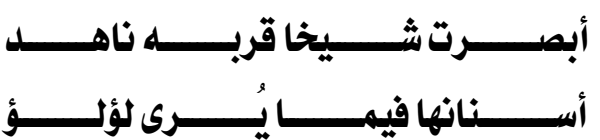

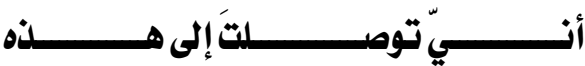

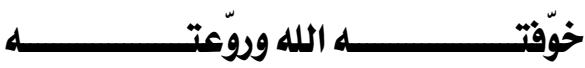

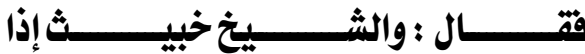
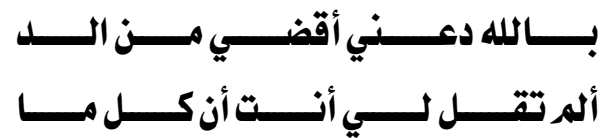

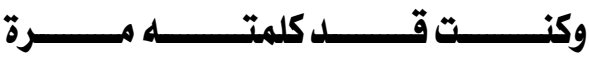

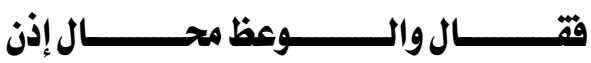

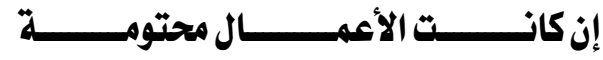

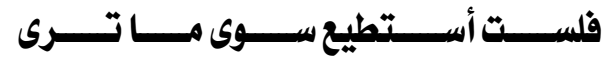
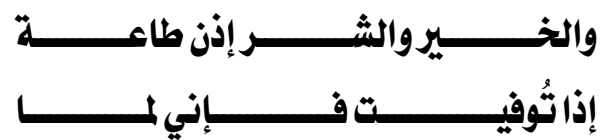

فالسرد هنا يقوم على وسيلة مهمة من وسائله وهي الوصف ، حيث يحتوي

صور من الحركات والأحداث ، كما يقوم على الحوار بين السارد/الثاعروالبطل،ومن ثم يتدخل الثاعر في الحدث ويقوم بدور الواعظ دون جدوى.

إن هذه القضية الاجتماعية العامة التي ساقها الثاعر في قصته تعدُّ امتداداً للقصة السابقة، ولكن الفرق أن الفتاة في القصة الأولى حرّة، ومن ثم جعل لها حرية التهاعية 
الاختيار ، أما هنا فالفتاة مملوكة لهذا الثيخ الكبير ، وليس لها حق الاختيار أو الكلام والرد، ومن ثم جاءت الأحداث متوالية، والبناء القصصي نامياً ومتطوراً.

كما أن سياق الحكاية الشعرية توضح اتخاذ هذا الثيخ موقفا فكريا يعتقده وهو

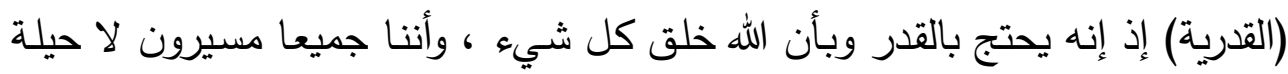

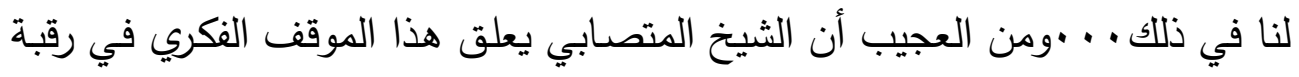

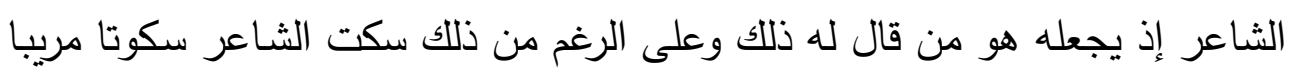

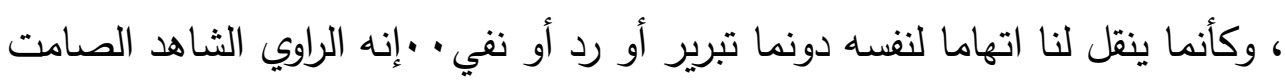
الذي لاحيلة له مطلقا.

وقربب من هذا الحدث السابق حدث آخر ، ولكن هذه المرة يدور بين الثـاعر

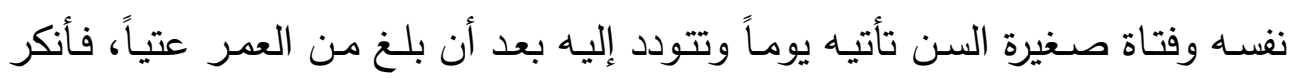

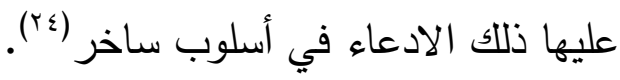
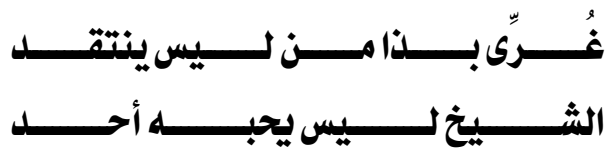

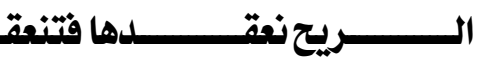

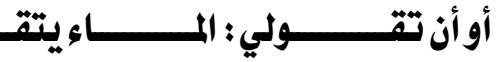

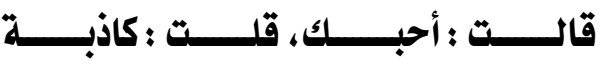
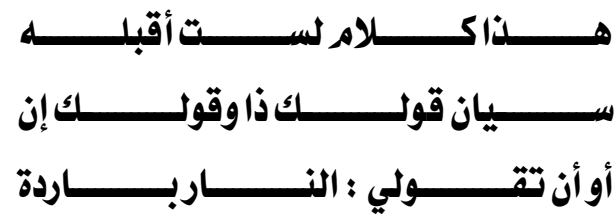

فالغزال من خلال هذا الموقف يظهر لنا بخبرته الواسعة، ودعابته الساخرة،

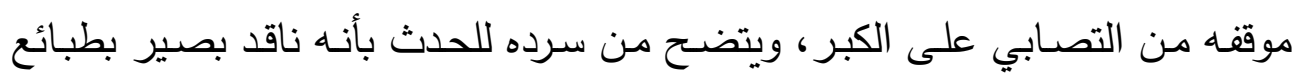
النساء، فهو يلخص القضية كلها في قوله : (( الشيخ ليس يحبه أحد )). وموقف الغـزال مـن هذه الفتـاة يختلف تمامـاً عـن موقفهـ مـن الإمبراطورة

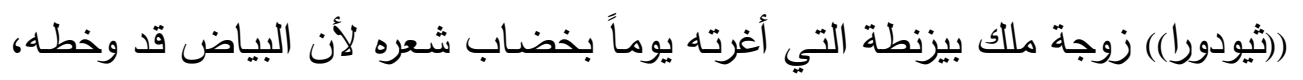
وكان الغزال وقتئذ قد أشرف على الخامسة والسبعين من عمره، وكان سفيراً للأمير

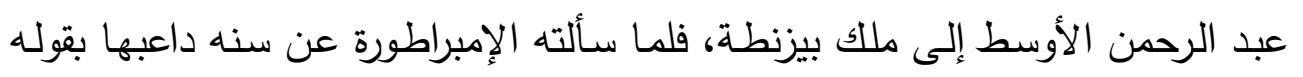


((عشرون سنة))، فتعجبت وقالت : وما هذا الشيب ؟! فقال : وما تتكرين منه ؟ ألم ترى قط مهراً يولا وهو أشهب(ro) :
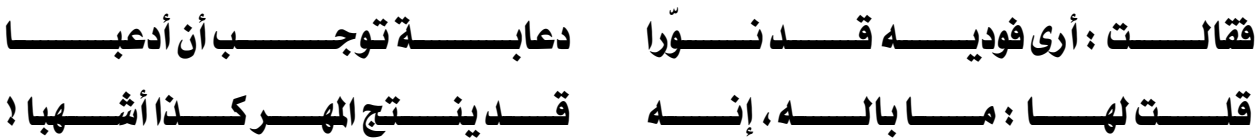

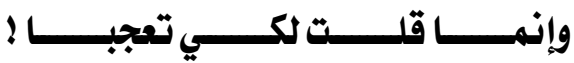

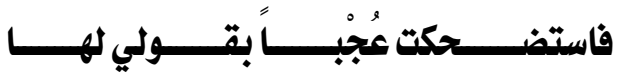

والظاهر في هذه المقطعة أن الغزال قد تغير موقفه تجاه المرأة، ولكنا نقول إنما هي روح الدعابة التي تميز بها الغزال رداً على دعابة الإمبراطورة، ومـع ذلك خضب شعره بناء على طلبها، فلما رأته استحسنت سواد خضابه، ولكن الغزال الناقد البصير يرى أن الشيب والخضاب عنده كالشمس المغطاة بالضباب، وأن المشيب هو زهرة الأفهام، ودليل التعقل، حيث يقول(بr) :

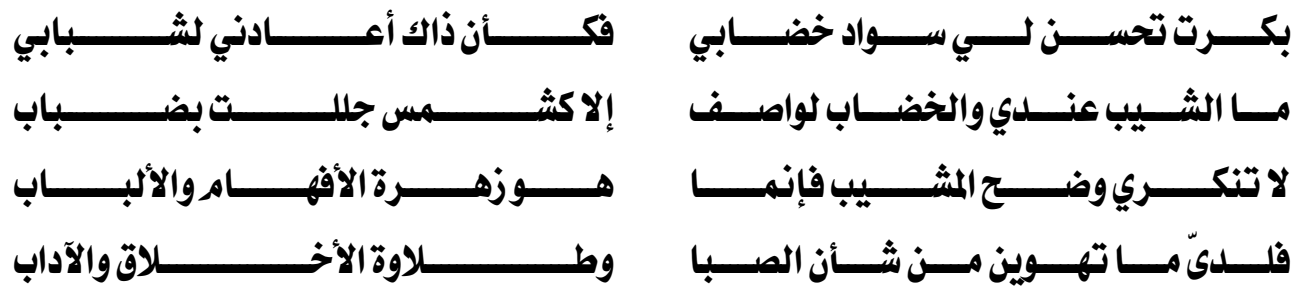
فالقصة وأحداثها ساقها الغزال في أسلوب سردي يقوم على التصوير والإقناع من خلال حدث ذاتي يتخلله الحوار الظريف المفعم بالدعابة وروح المرح وخفة الظل

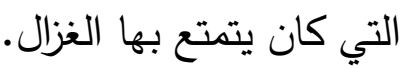
وتكتمل أحداث القصـة عندما جاءته الملكة ذات ليلـة ومعها ابنها الصـغير الذي يحمل زق خمر ليشربها مـع الثـاعر ويبيت عنده، وفي أسلوب سردي حواري يقص علينا الغزال ما دار بينه وبين الإمبراطورة(rV) : 

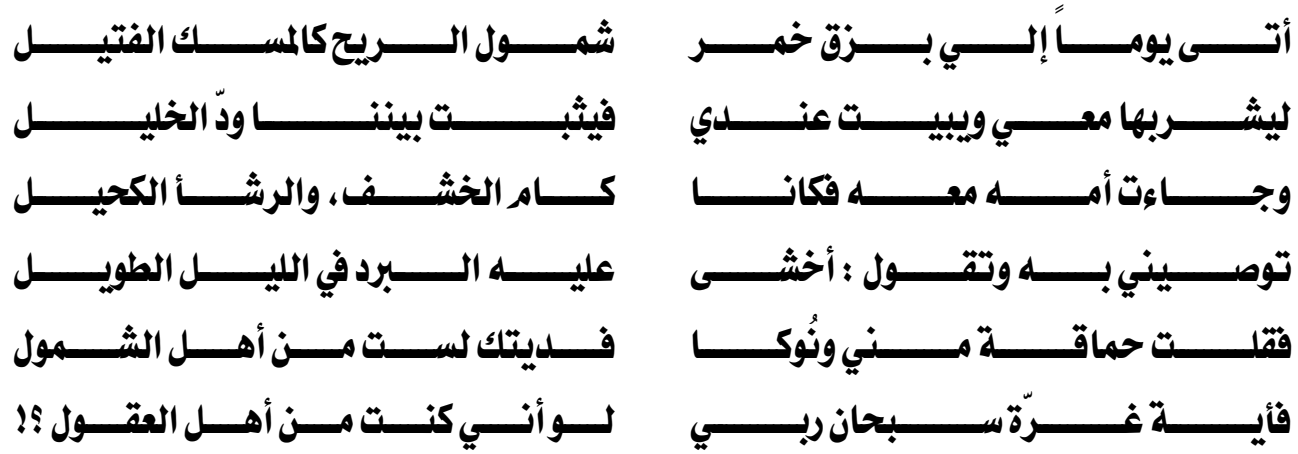

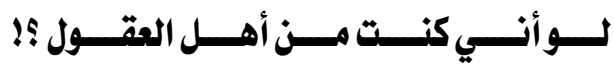

فعناصر السرد من أحداث وشخصيات وزمان ومكان تتوفر في هذه القصة فحدثها ذاتي يدور حول لقـاء ليلي جمـع شخصيات القصـة(الإمبراطورة وابنها) مـع السارد/البطل /الثاعر الذي رواها بعلم ووعي رواية مباشرة يتخلله حوارووصف أضاءا الحدث.

تمتع الغزال بخفـة الظل وروح الدعابة، والذكاء والفطنة، وكل ذلك أدى في النهاية إلى قص مشاهد كثيرة أظهرت مواهبه، وربما كانت هذه المشاهد من عوامل نجاح الغزال في سفارته، (( إذ أنس به ملك الروم وزوجته )(^^).

ونصل مع الغزال إلى قمة الفن القصصي، واكتمال عناصره الفنية من خلال

تلك الفتاة التي خرجت إلى الثاعر وثوبها مقلوب وقلبها مضطرب، حيث سرد قصته معها مازجاً ذلك السرد بصفات الفتاة ومنها جمال الابتسامة، ورشاقة القّد، فيشتاق إلى الضـلال معها، وقد حسبته مغرماً بها، فلما ضمها إليه لانت لـه في استرخاء، ومـع هذه الذروة من الأحداث، وقمة التشويق فيها، تأتي النهاية مخيبة للآمال، حيث تحللت نفسه، ووقف عاجزاً أمام رغبة الفتاة طوال الليل حتى لاح نور الصباح فيسألها : ألك حاجة؟ فتسخر منه وتسبه بأمه(rqr). 

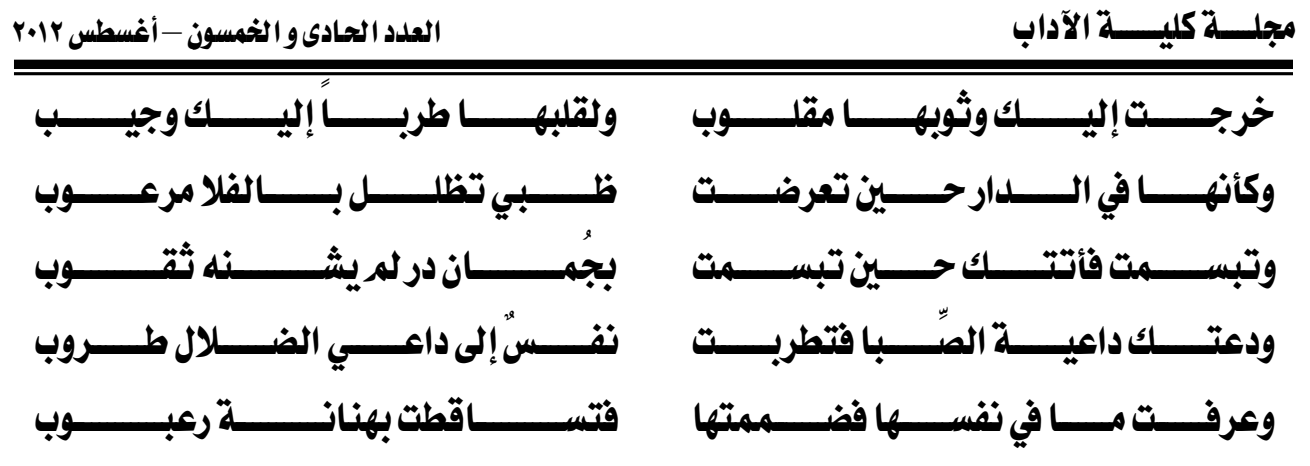

وبعد هذه المقدمة التي سردها الغزال لهذه الفتاة، وعرض صفاتها، يصل بنـا إلى ذروة الأحداث وقمة التشويق والإثارة، حيث يرغب فيها، وترغب فيه، ولكن الغزال يقف عاجزاً أمامها، فتحلل نفسه ويذوب قلبه، ثم يحكي لنا رد فعله، حيث يقول:

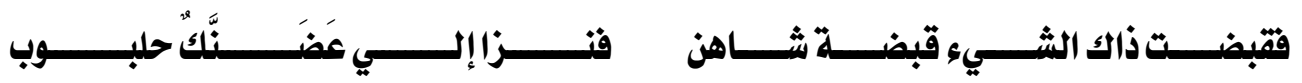

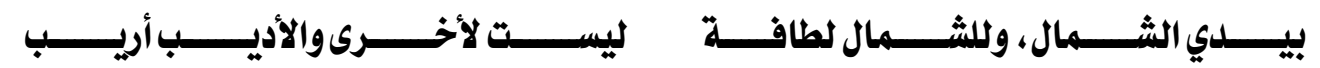

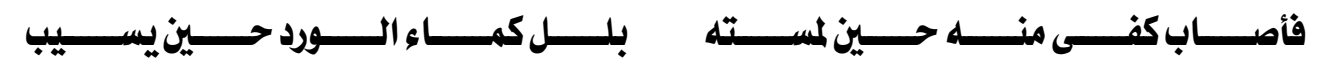

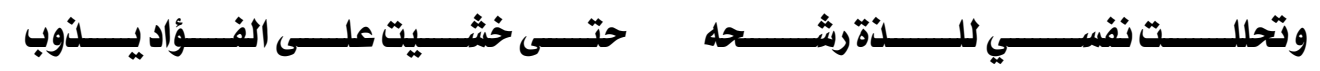

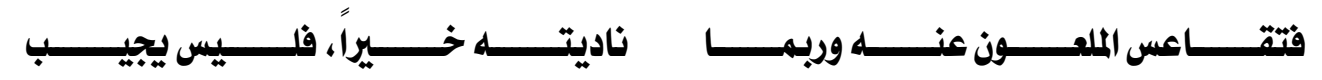

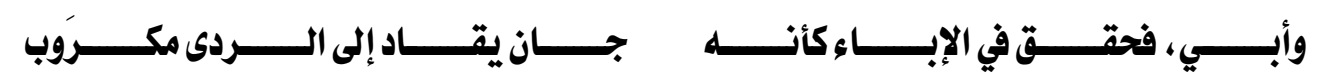

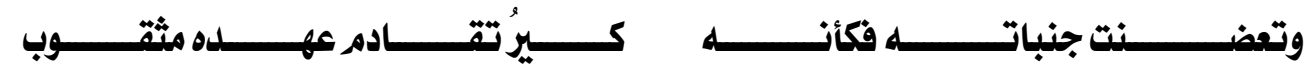

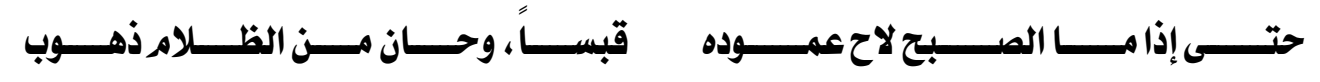

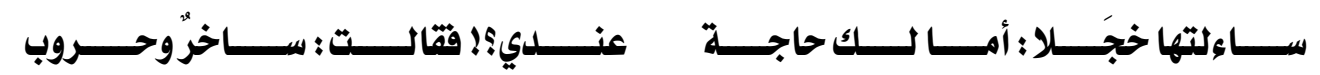

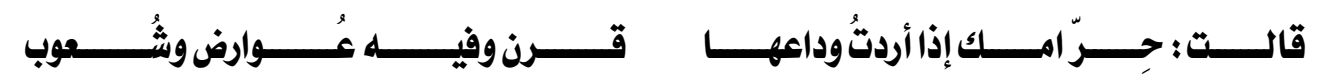
فهنا يطالعنا الراوي العليم بالسرد على وفق النظام التتابعي لحدث واحد (لقاء الشاعر مع الفتاة) ، ثم يسرد بعد ذلك التفاصيل الأساسية والثانوية لذلك الحدث مـع عدم إغفال الوصف الذي ساقه لتلك الفتاة والذي غطى مساحة كبيرة من دائرة الحدث، وقد سـاق الشاعر ذللك الحدث من خـلال السرد المباشر مختتما إياه بحوار دار بينه وبين الفتـاة، والسـارد هنـا بوصـفه راويـا ذاتـي القصـة يـروي حـثنا في غايـة الإثـارة والتشويق. 
والقصـة كمـا سـردها الغـزال تكتمـل فيها عناصـر القصـة مـن مقدمـة وأحداث

تتلاحم وتصل إلى قمـة التشويق والإثارة، لنصل في النهايـة إلى الحل، وهو عجز الشاعر عن مجاراة الفتاة.

ويبدو أن الثـاعر أراد أن يسـكمل قصـته السـابقة فسـرد لنـا قصـيدة أخـرى

تختلف عن السابقة وزناً وقافية، حيث أراد أن يبحث عن حل أو علاج لعجزه بعد أن تقاعس أمام الفتاة، وعجز عن تحقيق رغبتها، فطرق باب الطبيب الذي أخبره بأن شـبابه قد ولى، ونصـحه بشـرب العسل دون جدوى، فعـاد مـرة أخرى يطرق أبـواب الأطباء فأخبروه بأن سبب عجزه هو ذهاب شبابه، فللشيخوخة آثارها، وتأتي النهاية المؤلمـة، حيث يحزن الشـاعر ويرفع صـوته بالبكاء عندما حسم لله الطبيب القضية قائلاً : ماذا تريد يا رجل ؟! فمثلك مثل من حضرته الوفاة، فهل يمكن لطبيب أن يمدّ

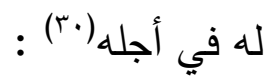

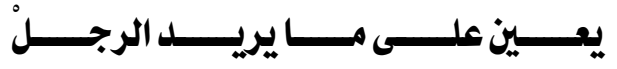

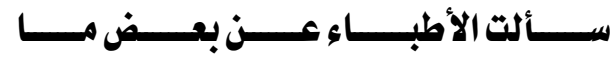

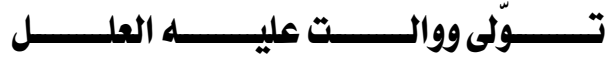

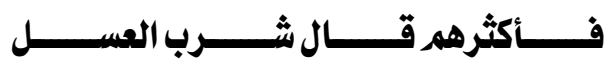

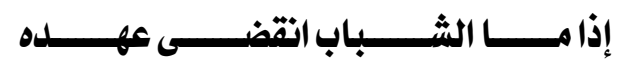

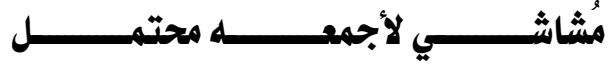

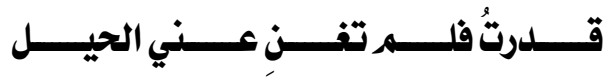

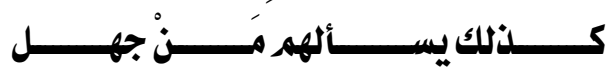

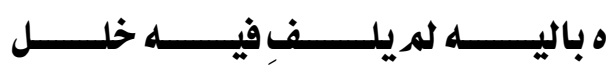

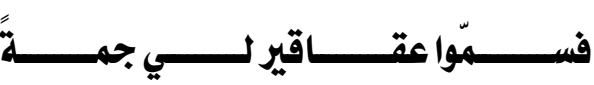

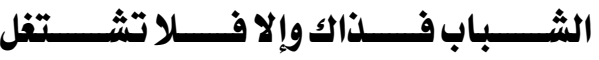

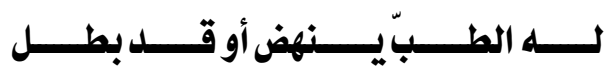

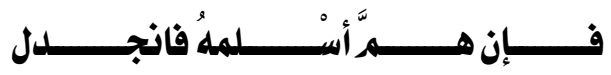

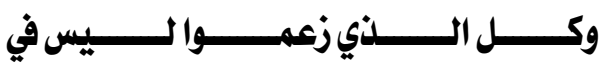

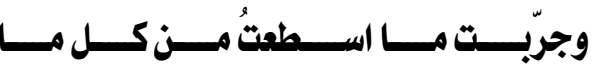

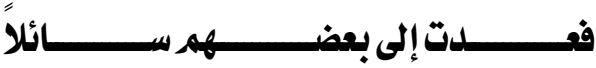

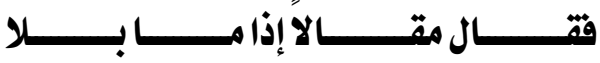

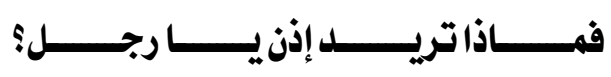

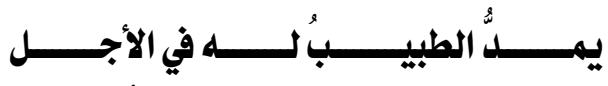

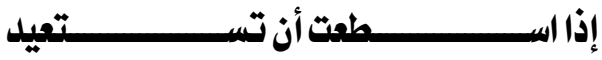

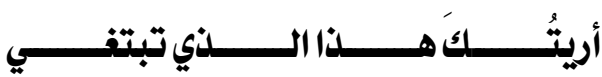

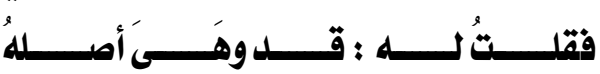

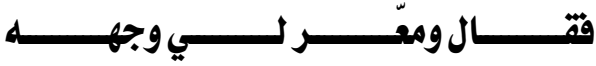

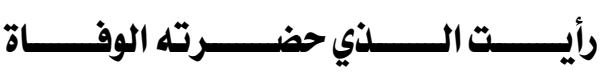

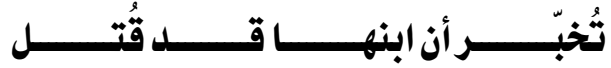

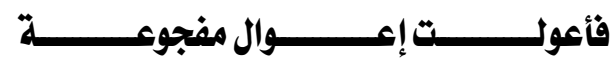


فالقصة الثعرية السابقة لا تكتفي بحدث واحد، وإنما يتفرع من الحدث الرئيس أحداث ثانوية، فالحدث الرئيس في القصة كلها هو لقاء الثاعر بالفتاة ورغبتها فيه، وتشوقه إليها، ثم يتفرع عن ذلك أحداث أخرى، وهي عجز الغئ الغزال عن مجاراة الفتاة،

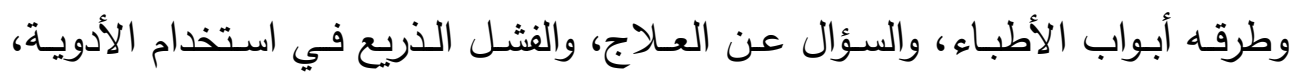
والنهاية الحزينة للقصة الطويلة.

ويرى الدكتور علي الغريب أن الغزال وصف نفسه بالعجز عن مباشرة النساء

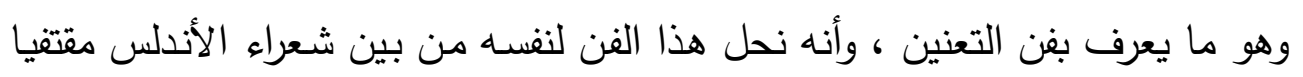

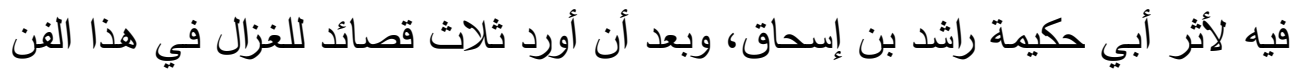

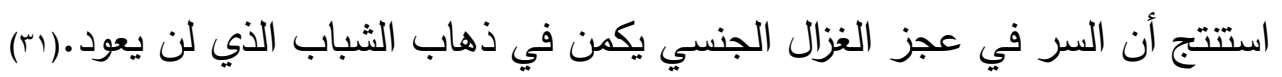
وأرى أن الغزال نظم قصته السـابقة ليثبت مقدرته الثعرية وتفوقهـ في هذا

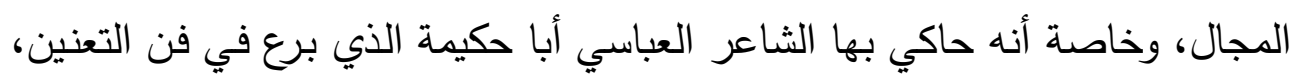

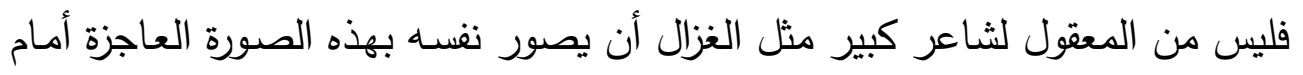
النساء، ولذا فهي أقرب إلى الدعابة والظرف والسخرية التي تمتع بها شاعرنا، ومحاكاة الثاعر العباسي أبا حكيمة في قصيدته التي مطلعها يرثى متاعه(بr) :

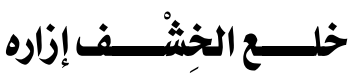

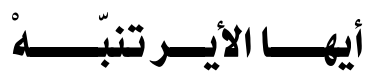

وللغزال قصـة طريفـة أخرى هـع الأمير عبد الـرحمن الثاني أودت بـه إلى وهى السجن، وهي قصة ((الأهراء)) وخلاصتها أن الغزال قد تولى قبض الأنيز الأعشار واختزانها

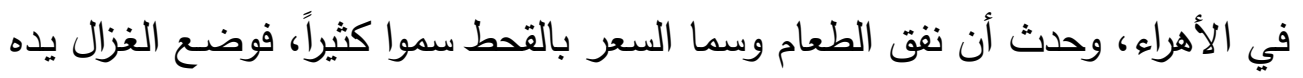

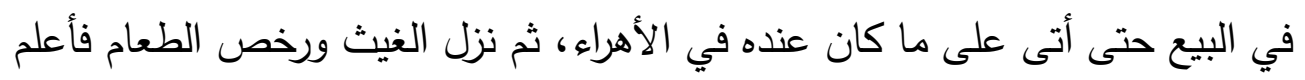

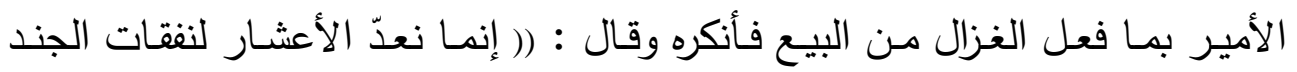
والحاجة إليها في الجهد، فماذا صنع الخبيث ؟! خذوه بأداء ما باع واشتروا به طعاماً،

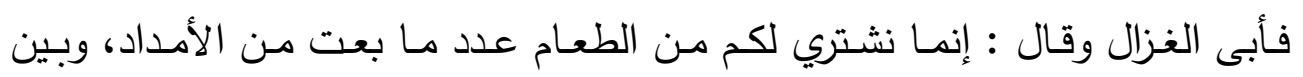


العددين بون شاسع في الثمن، فأعلم الأمير ، فأمر بسجن الغزال، فقال مصوراً أحداث القصة بعد أبيات مدحه فيها(r) :
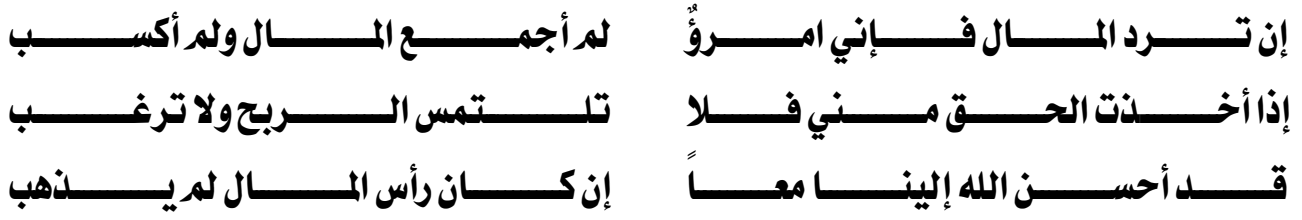

ولما رفعت القصيدة إلى الأمير أعجب بها وأمر بإطلاق سراحه.

\section{ثانياً : الشخصية :}

إذا كـان الحدث هو أحد أهم عناصـر القصـة، فـإن الشخصية لا تقل عنـه

اهتماماً، ولا يمكن الفصل بينهما، أو الاستغناء عن أحدهما، فلا يوجد فعل بلا فاعل، يقول بارت: (( لا يوجد أي سرد في العالم دون شخصيات، ومن ثم فالشخصية تمثل

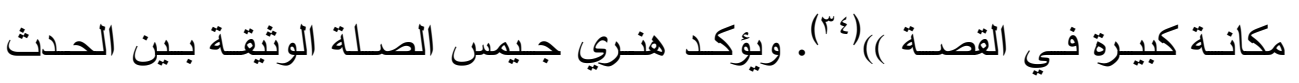
والشخصية حين يتساءل (( ما الشخصية غير تقرير الحدث، وما الحدث غير تصوير

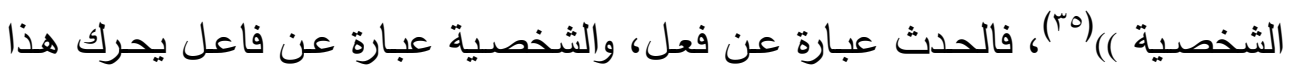
الفعل على أرضية الواقع أو أرضية النص، وعليه فإن الحدث والشخصية يدخلان في علاقة تواشجية لا يمكن فصلها.

وقد تبدو الأحداث مفككة، لا وحدة بـين أجزائهـا، لكن وجـود الشخصيات

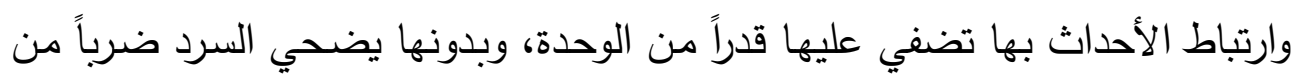
الوصف التقريري( آ؟ب).

وإذا كان النقاد يقسمون الشخصية في العمل الروائي إلى شخصية مسطحة

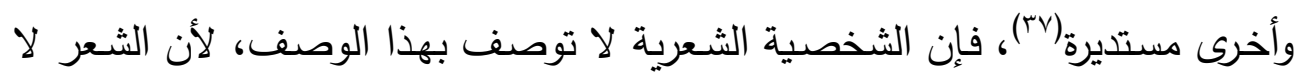
يحتمل المواقف المتعددة أو المتطورة، وإنما يقوم على موقف واحد أو حدث واحد. 
وحتى تؤدي الثخصية دورها في العمل القصصي الثعري فإن تقديمها قد

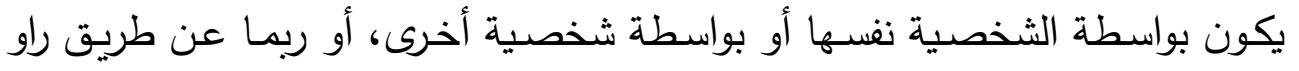

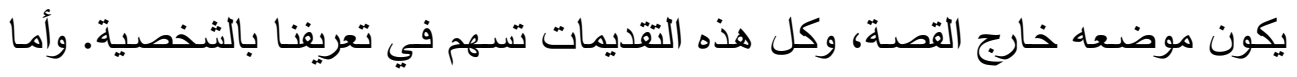
رسمها فقد يكون عن طريق وصف المعالم الخارجية والجوانب الثكلية محاولاً تفسير بعض تصرفات تلأك الثخصية وإعطاء رأيه فيها (^).

يقول الغزال واصفاً حالته (شخصد) مع الكبر عندما سألته أم عمر(ª") :

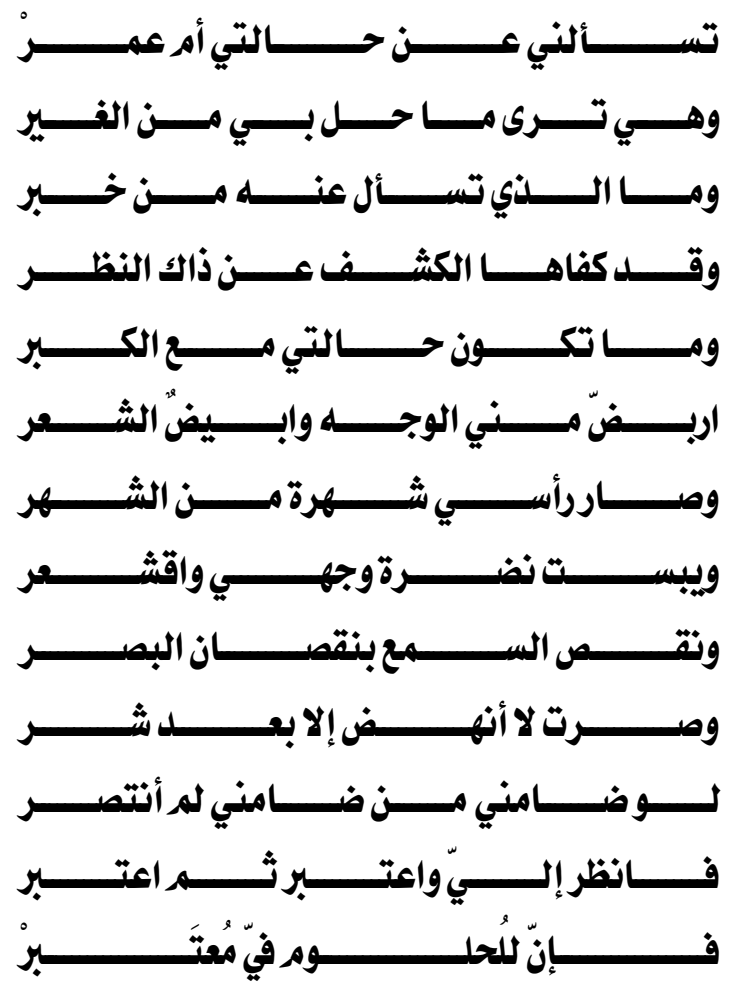

فهذه الحالة التي وصل إليها الغزال من الكبر ، والأوصاف التي ساقها لنفسه

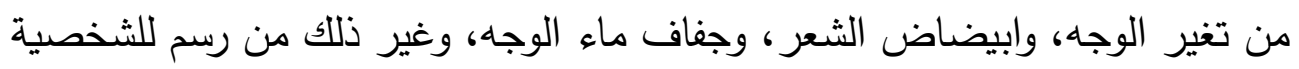

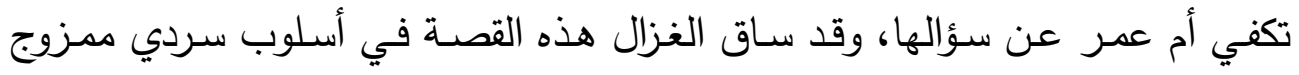
بالوصف عن طريق السؤال والإجابة المسهبة، ومن الملاحظ أن الغزال هنا قد استبدل فعل الحديث بفعل القول، وفعل الحديث أو فعل القول لا يستغنى عنهما الحدث. 
ومن الشخصيات التي رسمها الغزال بعناية فائقة، وقدّم لنا بعض ملامحها الخارجيـة مـن خـلال تصـرفاتها، وقـد أعطىى رأيـهـ فيهـا، شخصـية القاضـي يخـامر الشعباني الذي وصفه الغزال بالجهل، حيث قرأ عليه أحد الغلمان سورتي (طه وغافر) فأنكرهما، وقال متعجباً إن هذا الكلام لشاعر مجيد، وفي نهاية القصة يستهزئ الغزال

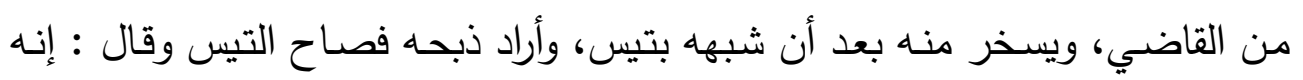

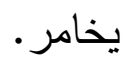

فمن خـلال الوصف المباشر تم تحديد سمات شخصية يخامر ، ( فكل فعل تقوم به الشخصية، وكل قول يصدر عنها مخبراً عن هويتها، وعلى القارئ حينئذ أن يـؤول الأفعـال والأقوال، ويصـف الشخصـية الوصـف الذي يـراه حتى تكتمـل عنده هونه صورتها)(|•). ولذا يقول الغزال في هذا القاضي يخامر (اء) :
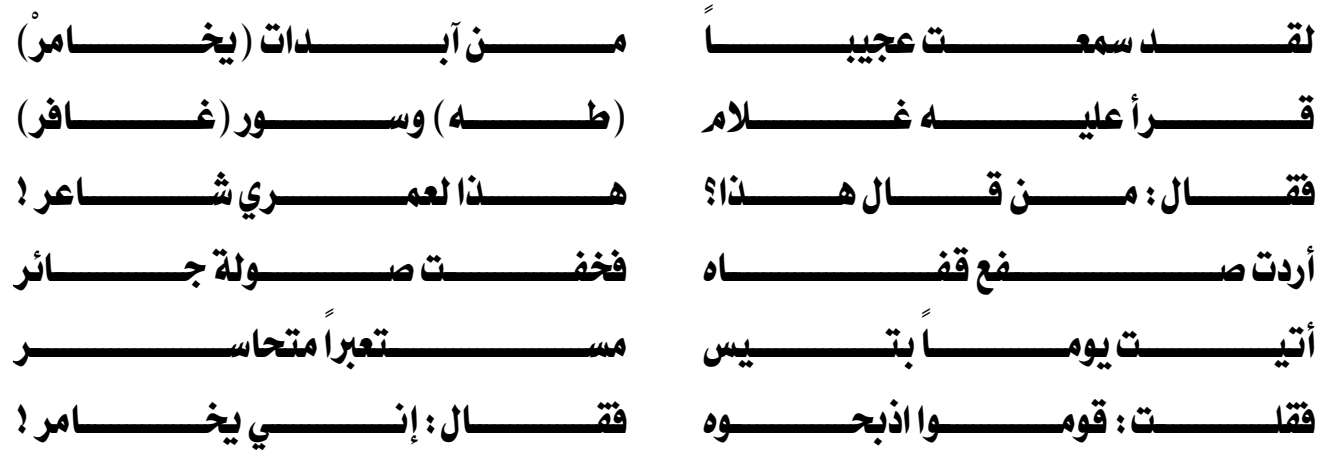

وبهذه الطريقة التي تدعى بالتمثيلية عن وصف الشخصية، واستتتاج صفاتها

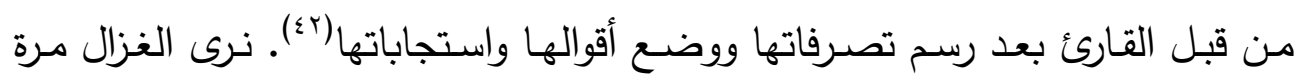
أخرى يصور القاضي يخامر في صورة إنسان تقلد صنعة ليست لله، وأنه غير جدير بهذا المنصب؛ لأنه جاهل متخبط في أحكام الدين، فهو كالذباب الذي يحمل الصخر

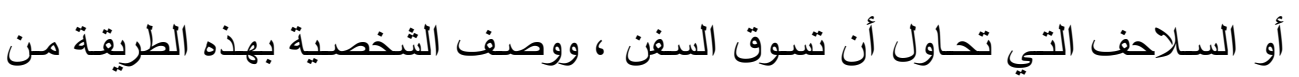
خـلال عيني السـارد يدل على جهلها وغبائها، وقد أسـهم هذا الوصف في كثف

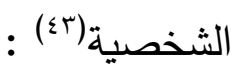




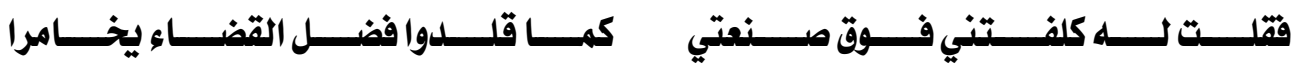

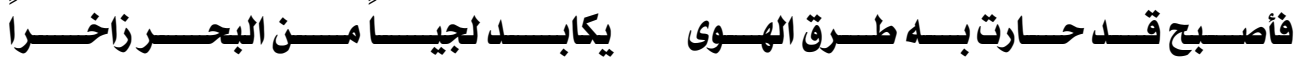

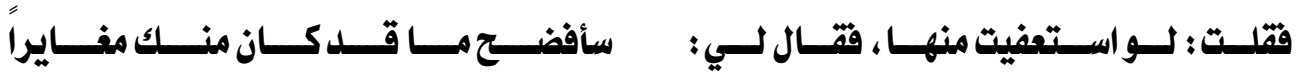

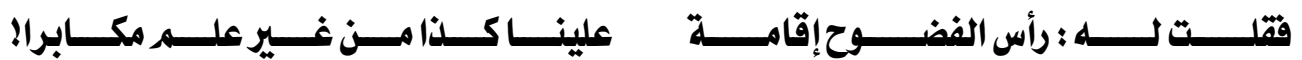

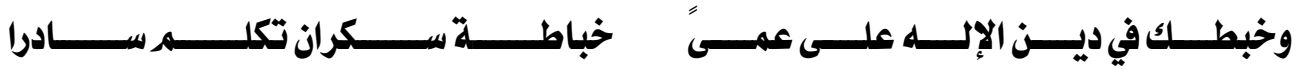

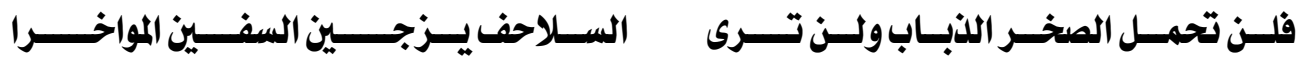
ومن الشخصيات التي قدمها لنا الغزال في فنة القصصسي شخصية المرائي المخـادع الذي يخـدع النـاس بتلونـه، واصـطناع أحسوال أهـل الصــلاح والخيـر وذوي المكانة والسلطة من خلال سرد حواري قائم على الاستهزاء والسخرية والإضحاك على

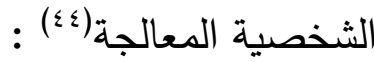
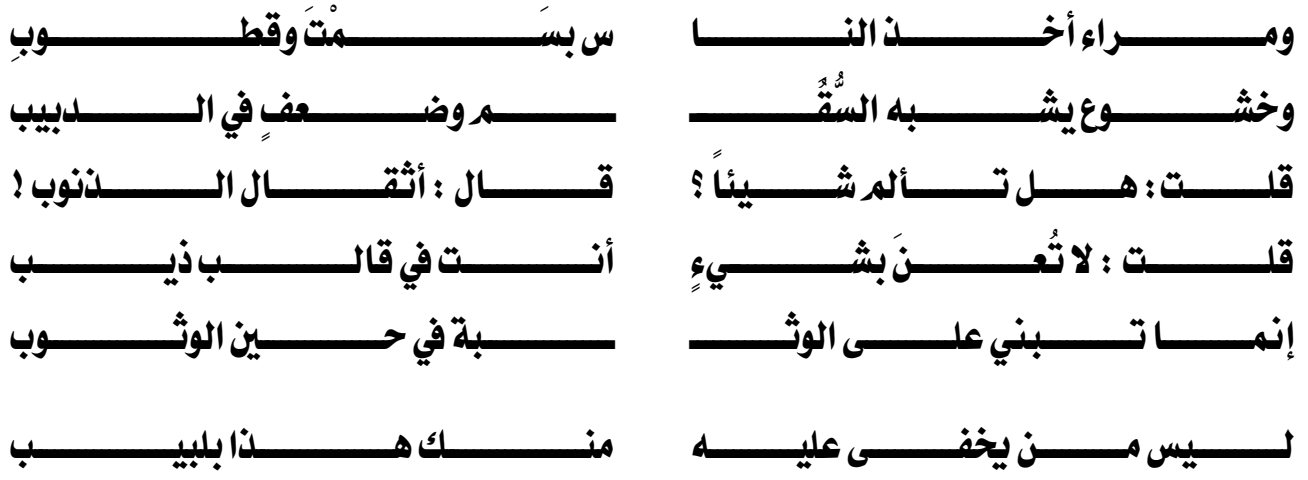

ومن شخصيات الغزال التي قدمها لنا في شعره، ووصفها وصفاً دقيقاً، يجمع

بين الوصف الحسي والوصف النفسي، تلك الجاريـة التي خرجت إليه وثوبها مقلوب ووصف حالته معها، وقد سبقت الإشارة إليها في مبحث الحدث، ومطلع القصيدة(0؛) :

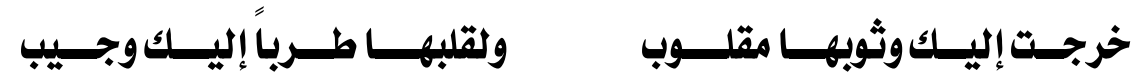
وشخصية الفتاة أو المرأة بصفة عامـة تحتل في الفن القصصي عند الغزال مكانة كبيرة، فقد قدمها حرَّة تارة، ومملوكة تارة أخرى، وساقطة متبذلة تارة ثالثة، وفي 
كل مرة يقدمها الغزال في إطار فني رشيق، وأسلوب قصصسي رائع، يرسم ملامحها الخارجية تارة، ويسبر أغوار نفسها تارة أخرى، ولم لا ؟ والغزال خبير بأسرار النساء، عليم بأحوالهن، عارف بخباياهن، ناقد بصير ، ويبدو أن إحداهن قد لعبت به في مقتبل حياته فأخذ من النساء جميعاً موقفاً يكاد يكون عدائياً، ويظهر هذا الموقف في نعتهن بقوله (57) :
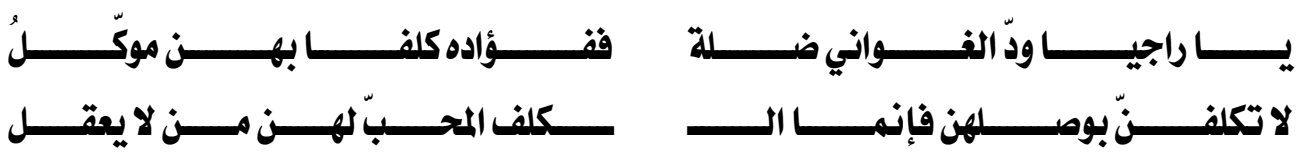

والغزال بخبرته الواسعة وتجاربه العديدة يختتم لنا قصته مع المرأة في أسلوب

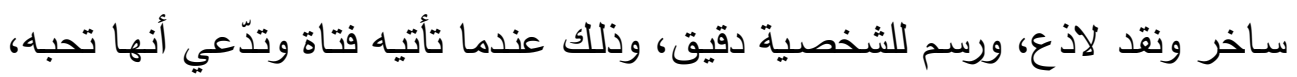
فيعرف نفاقها وكذبها لأنه يؤهن بهذه العبارة (الشيخ ليس يحبه أحد)( إ) :
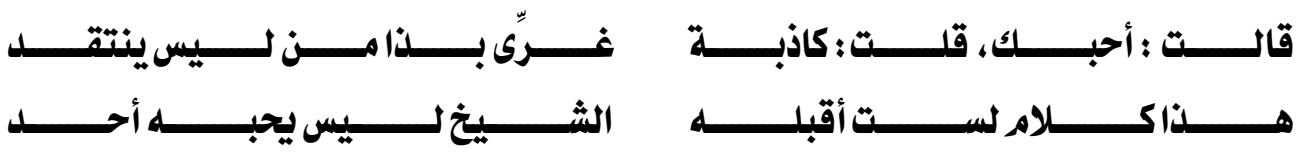

ومما يؤكد خبرة الغزال وعلمه بأسرار النسـاء وطبعهن تأكيده على أن تعلق

الفتاة بالثيخ الكبير إنما هو خداع له حتى ولو أظهرت حبها، فقلها سقيم، وبذلك يظهر لنا موقفه من التصابي على الكبر من خلال رسمه لشخصية هذه الفتاة(^؛) :

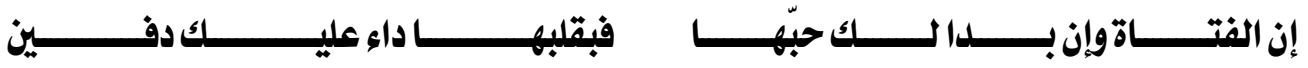

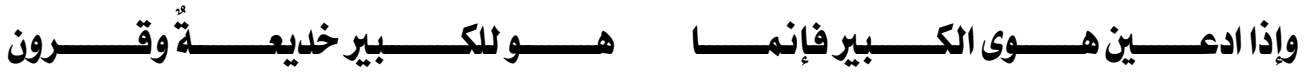

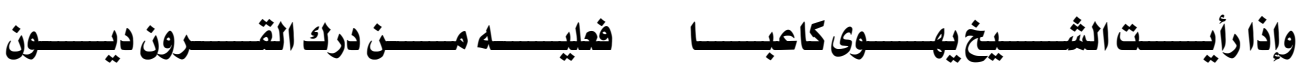
ولا يقتصر الغزال في تصوير شخصياته ورسم ملامحها من عالم الإنس وحسب، وإنما يستخدم عالم الحيوان في رسم بعض الشخصيات، ومن ذلك الصورة التي رأيناه فيها يجر (تيسا) للذبح، فاعتذر التيس مستعبراً متحاسراً وقال إنه يخامر (9ء) : 

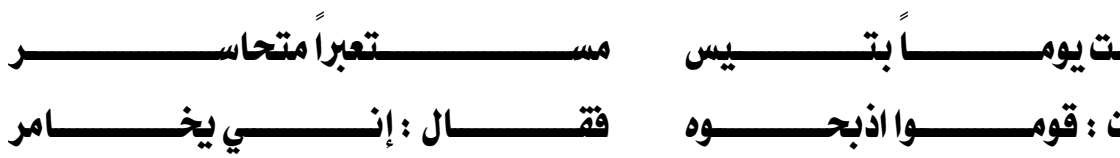

وقد دار حوارٌ بين الشاعر وديكه لما وقع الشاعر ضحية شهادة الزور فرثى

$$
\text { الديك لحال صاحبه حين اشتكى إليه(0) : }
$$

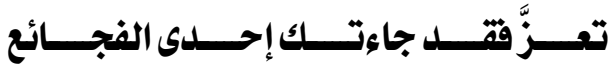

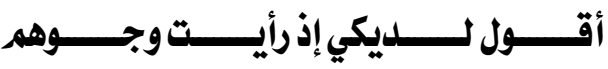

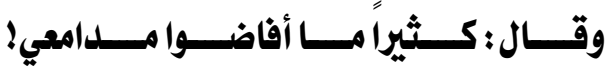

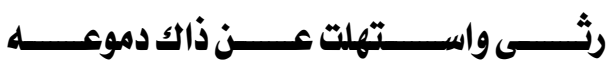

ولا يخفى مـا في هـاتين الشخصـيتين اللتين اسـتخدمها الشـاعر مـن عـالم

الحيوان من صورة تشخيصية تقوم على عنصر الإضحاك والسخرية.

وهكذا تتوعت شخصيات الغزال في قصصسه الشعري، قدمها، ووصفها وصفاً

حسياً أو وصفاً نفسياً، أظهر ملامحها ومكنونها، عن طريق السرد القصصي الذي يتخلله الحوار أحياناً. ومع ذلك استطاع الغزال (( أن يرسم ببساطة المواقف، ويحدد

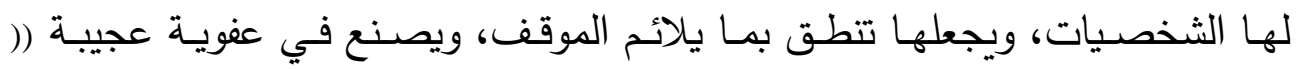
تراجيديا ()) مكتملة الأبعاد )(10.

المبحث الثاذي

وسائل السرد القصصي 
هو الكلام الذي يأتي على ألسنة الشخصيات في الفن القصصس، فإذا كان بين متحاورين يكون حواراً مـع الغير، وإذا كان بين النفس يكون مناجاة، وهو الذي يعطي للعمل القصصـي الروح ويمنحه الحياة، فالسـرد وحده غير قادر على إقناع القارئ بواقعية الأحداث، ومن ثم يؤازره الحوار •

بيـد أن الحـوار فـي الثـعر والقصـة لا يعـدّ عنصـراً أساسـياً، لأن الأغلبـة الساحقة من القصائد لا تحتوي في بنائها على الحوار، لأنه تكنيك مسرحي في أساسه

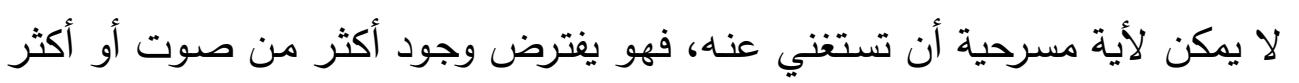
من شخصية، على أننا قد نرى بروزه كتكنيك أساسي في بعض القصائد إذ يتضاءل دور تعدد الشخصيات إلى جواره(من). ومـع ذلك يُسـهم الحـوار في تطور أحداث القصـة، ويكثف عمـا يعتمل في دواخل الشخصيات، ويكشف أيضاً عن أبعاد الحدث السردي، ويعمل على استحضار

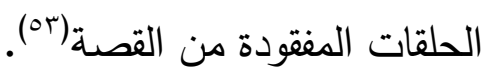

وإلى جانب الإخبار بالحدث، وتقديمه حياً نابضاً متحركاً، يقوم الحوار بالإبانة

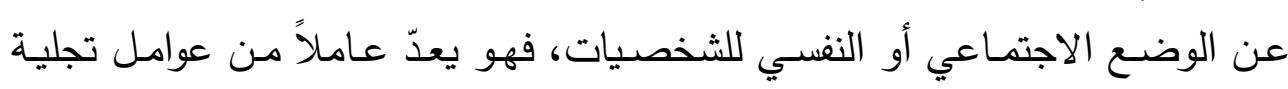

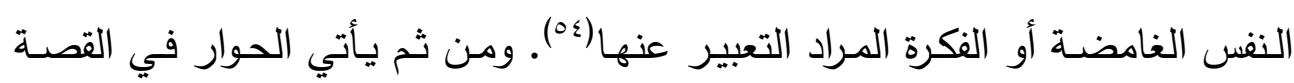

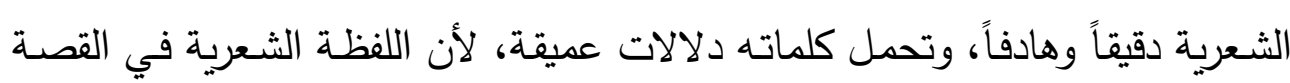
الشعرية تتسم بالجانب الجمالي وبالتأنق في التعبير • من اللافت للنظر أن الغزال في فنـة القصصـي الثعري قد استخدم الحوار كتقنية أساسية في شعره، سواء أكان هذا الحوار مفترضاً على وجود شخصية تحاوره، أم على ترك الحوار بين شخصيتين تتحاوران، وينأى بنفسه بعد أن يقدمهما للكشف هيف

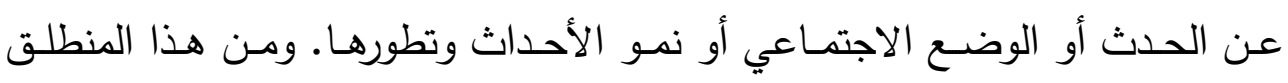
نلاحظ أن الحوار عند الغزال يمثله عنصران أساسيان، عنصر نسائي وآخر رجالي. 
ومن الأحداث التي اعتمد فيها الغزال على خصوصية الحوار موقفه من المرأة

بصفة عامة، والفتاة بصفة خاصة، وذلك عندما ترك الحوار بين الفتاة وأبيها لتحديد

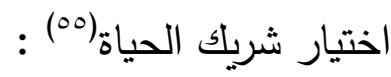
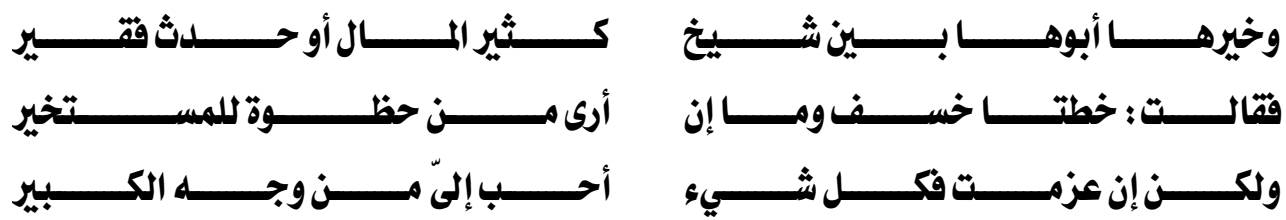

بني الغزال حواره السابق بين الفتاة وأبيها في أسلوب سهل بسيط غير متكلف، ليسوق موقفاً تبنـاه، وحدثا تدخل فيهه عن طريق شخوصـه، ومن ثم جـاءت أقوال الثخصيات متسقة مع طبيعتها، ولذلك يقول الدكتور شفيع السيد : (( يسوق الثاعر

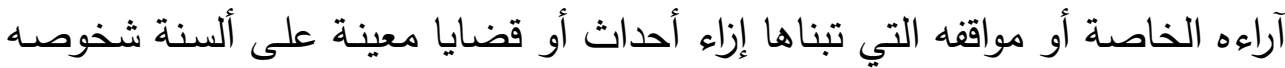

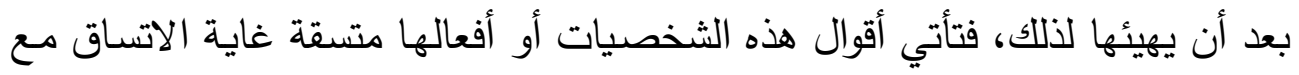
طبيعتها (07) بعذ نون فالفتاة وأبوها شخصيتا هذه القصة قد تعهدتا بالكلام دون أن نلمح أثراً لتدخل

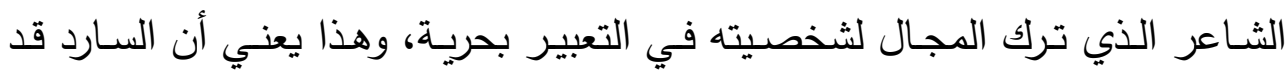

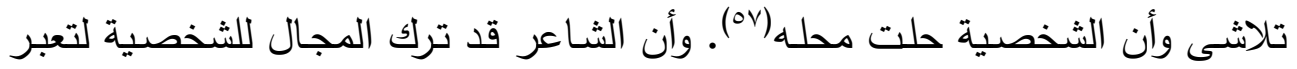
في سياق موقف الخطاب مباشرة بصوتها. وفي موقف آخر قريب من ذلك نرى الحوار قد دار بين الثاعر / السارد ومن

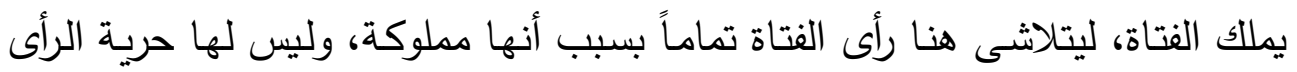

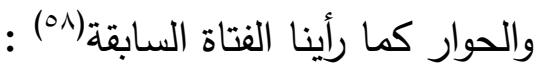
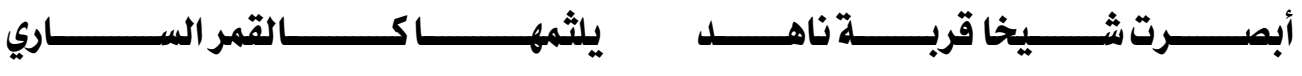
والنص كما هو واضتح يجمع بين السرد القصصي بأسلوب الوصف المباشر

الذي جـرى على لسـان الثـاعر/ السـارد، والسـرد الحـواري بـين الشـاعر وهذا الشـيخ المتصـابي، وتلاشى دور الفتاة فلم يكن لها حق الحوار لأنها مملوكة، وهذا ينم عن ذكاء الغزال ورؤيته الشعرية النافذة.

ويتميز حوار الغزال مع من يحاوره - في كثير من الأحيان - بالهدوء وعدم

الانفعال، وهذا يتضـح من رده على الفتاة الصغيرة التي أتته بعد أن بلـغ من العمر هر عتياً وقالت له أحبك فرد عليها مبيناً موقفه من التصابي على الكبر في أسلوب سردي حواري سهل وبسيط(09) :

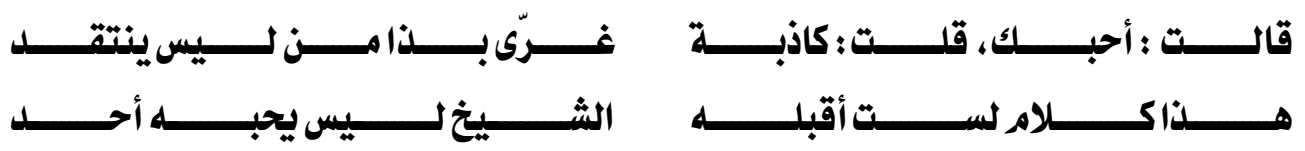

وفي حواره مع الإمبراطورة يتميز الحوار بالمرح والدعابة الفكهة وخفة الظل الرائعة، وذلك عندما سألته عن سنه، فقال (عشرون)، فتعجبت(·ج) :

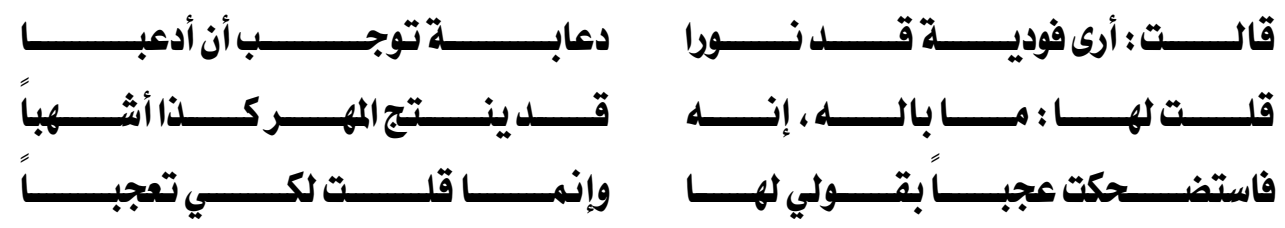

في المشـاهد السـابقة وجدنا الغزال كبطل لبعض قصصـه يستخدم في حواره فعل القول الذي يقوم عليه الحدث، ويكرره ليكون أبعد أثراً في المتلقي، وقد يستبدل فعل الحديث أو السؤال بفعل القول أحياناً، ولا يخفى ما تحمله هذه الأفعال من إثـارة

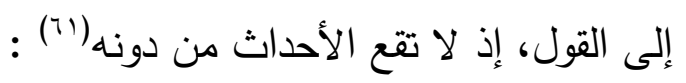

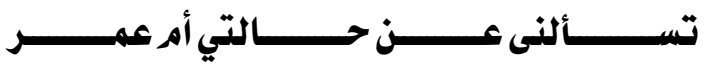




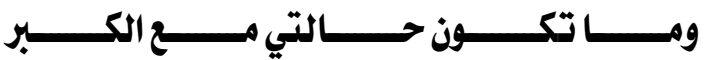

فسؤال أم عمر ، وجواب الثاعر، ييرز المشهد الذي سرده الغزال، وفي مشهد آخر يأتي الحوار عن طريق السؤال والإجابة في قوله(rآ) :

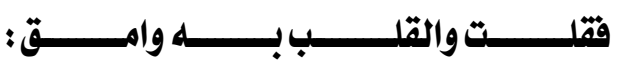

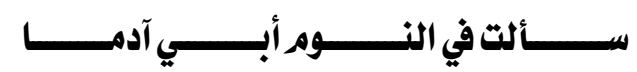

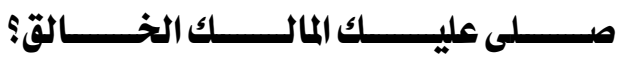

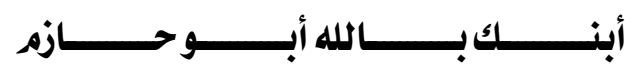

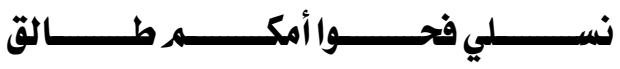

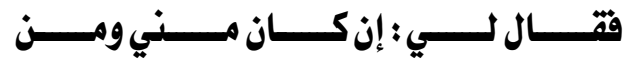

فالسؤال طريف والإجابـة لا تقل طرافة عن السؤال نفسـه، وهذا يتجلى في موقف آخر لما سأل الأطباء عن علاج لعجزه أمام الفتاة الراغبة فيه(rآ) :

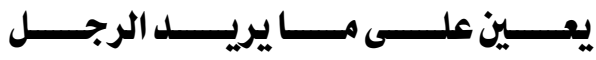

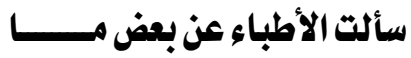

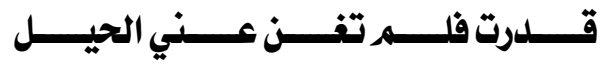

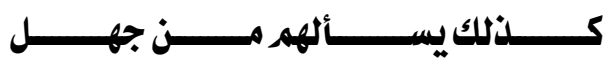

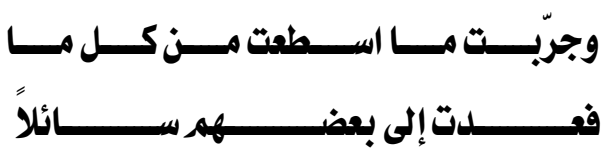

يتميز الحوار لدى الغزال بالبسـاطة وعدم التكلف والإسـهام في تسلسل الحدث أو تحريكه، وذلك عن طريق عبارات موجزة موحية، تحتوي على معانٍ كثيرة ولغة قرببة من اللغة الثعبية، فالموقف هو الذي يستدعي الحوار، وقد يطول وقد يقصر بحسب الموقف. وإذا كان الحوار قد تميز بالبساطة والرشاقة في المشاهد السابقة وخاصـةً مـع العنصر النسائي، فإن الحوار قد يسمو بلغته وثقافته وذلك عندما يدور مـع العنصر الرجالي كما نرصده بين الشاعر والقاضي يخامر الشعباني (ء):

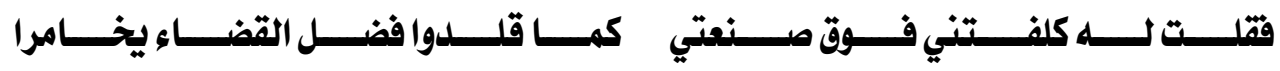

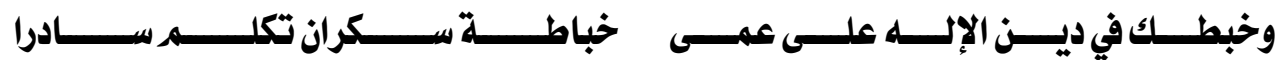

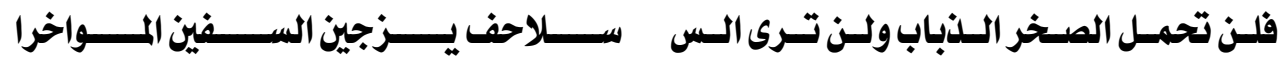


فالثـاعر يختـار ألفاظاً أعلى ممـا سبق لأنـه يخاطب رجـلاً مثقفاً، فكلمات (سادر - يزجي - مواخر) أبعد قليلا عن لغة العامـة، ومن ثم فقد راعى الثـاعر في اختياره المعجم اللفظي الشعري موافقة حال المخاطب، ولا يخفى ما في هذا الحوار بين الثاعر والقاضي من تسلسل للحدث الذي يبدأ بنصيحته للقاضي ثم يتصـاعد إلى خصومة بعد خبط القاضي في قضائه خبط عشواء من غير علم ولا هدى، ثم تأتي الصورة الشعرية لتؤدي في سياق الحوار وظيفة السخرية من ذلك القاضي، فهو غريق قضائه، يكابد فيه ظلمات كل لجة:

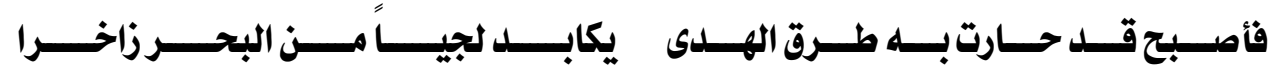

ويتآزر الحوار مع الصورة الشعرية حتى كأنها جزء منه، ولا تنفصل عنه، كما

يرسم الشاعر صورة دقيقة لشخصية القاضي الجاهل من خلال الحوار أيضاً.

يتفاوت الحوار لدى الغزال بين الإيجـاز والإطناب، فتارة يأتي سريعا موجزا

يقوم على السؤال والجواب لرصد حالة اجتماعية وبناء موقف منها، كما في حوار الشاعر مع المنافق الذي يكثف الحوار بينهما عن تللك الخصلة الذميمة (70).

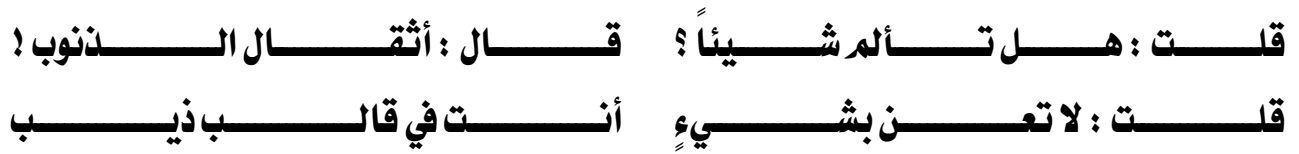

استخدم الغزال الحوار الرشيق في كثير من فنه الشعري القصصس، ليعري

الواقع، ويكثف مـا بـه من فسـاد اجتمـاعي تارة، أو يقدم من خلالهه بعض النصـائح والرؤى الشعرية تارة أخرى. كما غلب عليه عنصر الطرافة أو السخرية اللاذعة، وقد وجدنا الحوار عنده يقوم أحياناً على اللمحة الخاطفة، وأحياناً أخرى على بسط الحدث وامتداده بحسب ما يقتضيه الموقف. 


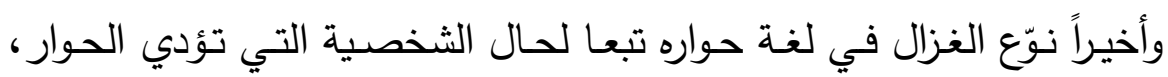

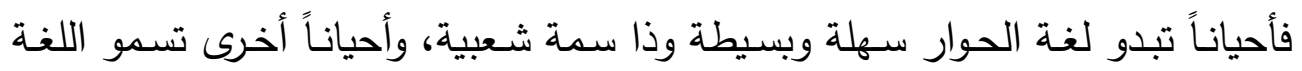

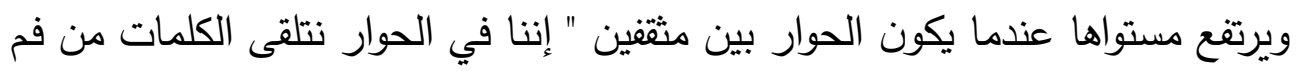

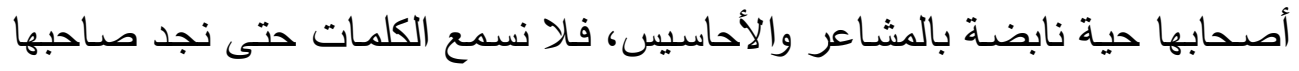

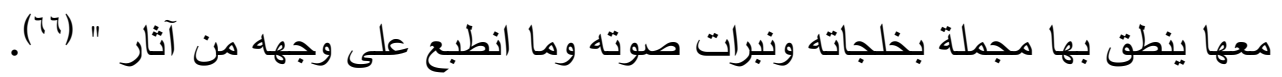

\section{ثانياً : الوصف}

بذأ الوصف يفرض وجوده في الدراسات النقية الحديثة، إذ احتل مكانة كبيرة من

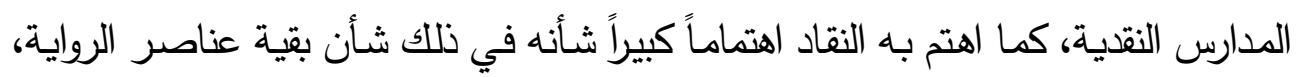

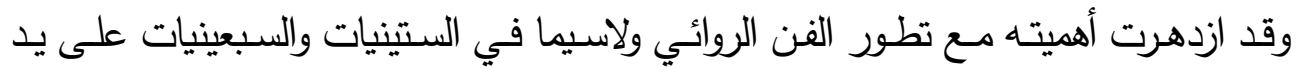

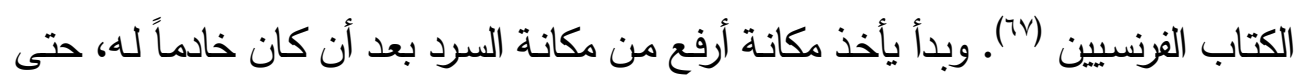

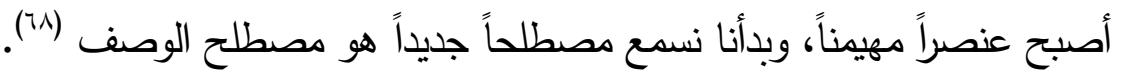

يقوم الوصف بدور كبير إلى جانب السرد والحوار، ويسهم بقدر كبير في

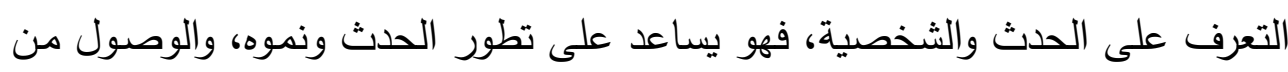

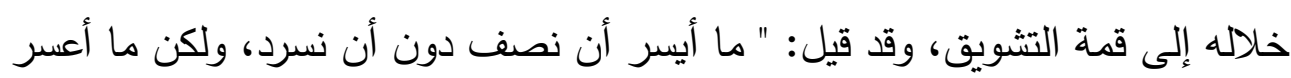

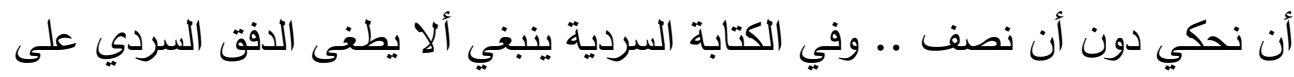

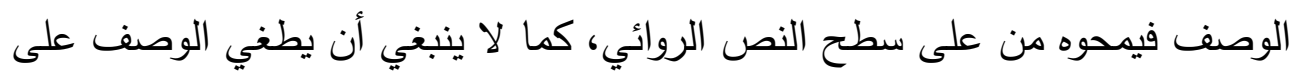

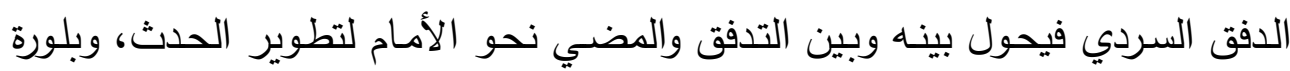
ملامح الشخصية، وما تضطرب فيه من حيز وزمان " (79). وإذا نظرنا إلى شعر الغزال فإننا نجد أن الوصف قد نهض فيه كوسيلة من

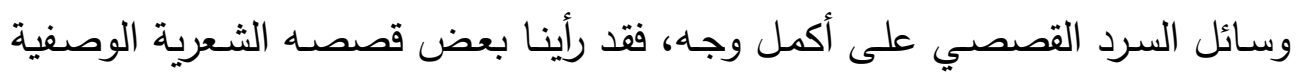

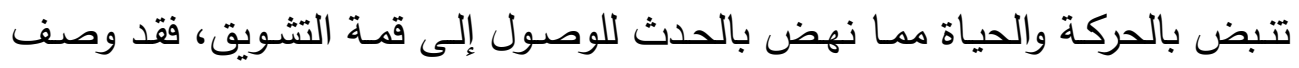

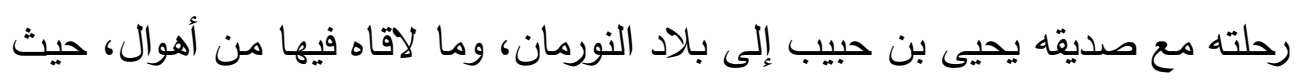


هاج البحر فوصف موجـه، واشتدت الرياح فوصف قلاع السفينة وحبالها، وأحاطت بهم المخاطر ، وأوشكوا على الهلاك، ولم يعد لهم طريق إلى النجاة (••).
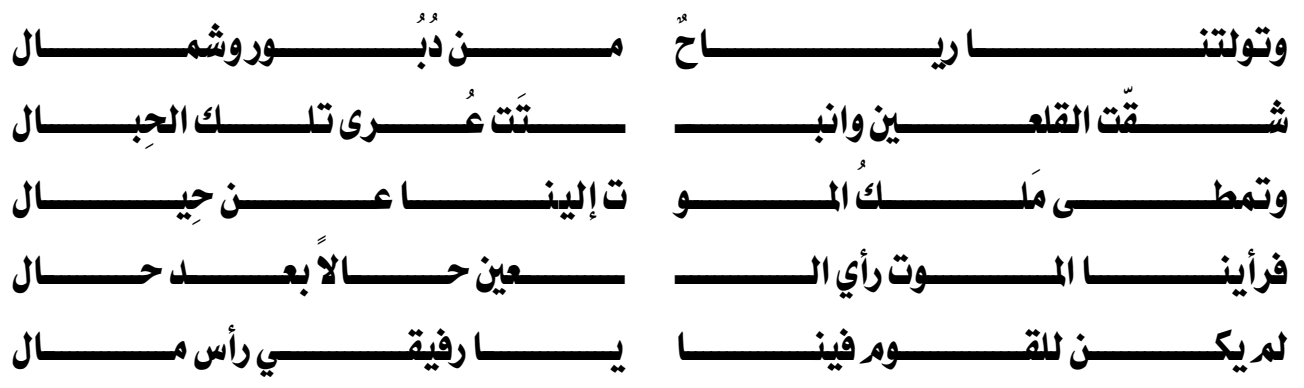

فانظر كيف تصاعدت الأحداث ووصلت إلى ذروتها من خلال هذا الوصف الذي باعد الشاعر فيه بين فعل القول في البيت الأول ومقول القول في البيت الأخير. ولا يخفى مـا في هذه الأبيات مـن تصـوير بـارع للريـاح تارة، وللمـوت تـارة أخرى، معتمداً في صوره على السرد الوصفي الذي أجاد فيه ومن ثم يرى الدكتور إحسان عباس أن " الغزال لا يزال في أثد حالات الكرب، ومع ذلك تشف نفسـه عن الفكاهة العذبة، وخاصة في قوله: لم يكن للقوم فينا يا صديقي رأس مال (IV). وقد يأتي الوصف في فن الغزال القصصسي تزينياً ليشكل إطساراً أو ديكورا للحدث، فيشبع الحاجة الجمالية لدى القارئ، وهذا ما خلعه الغزال على الأمير ميشيل

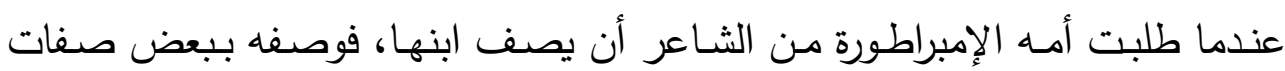
النساء الجميلة، فهو أغيد، ولين الأطراف، وكحيل الطرف ... الخ (VY). 


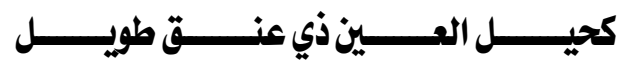
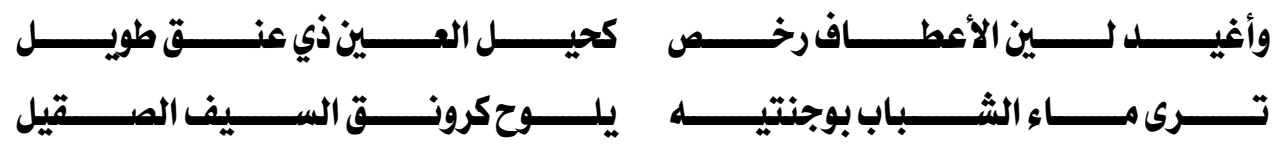

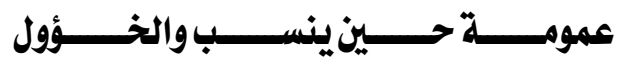

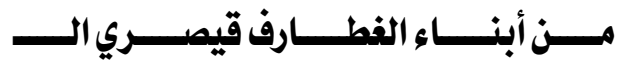

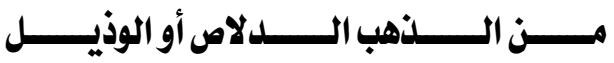

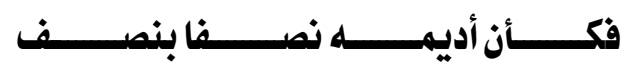

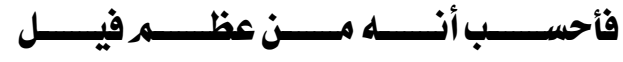
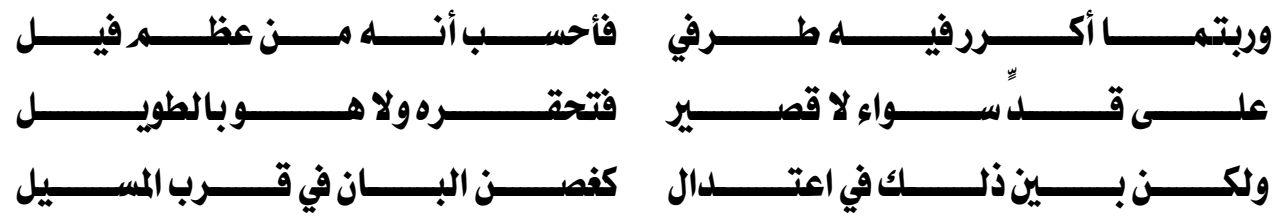

وإذا كانت الأبيات تنتمسي إلى شـر الغزال بالمذكر ، فإنها قد أضـافت إلى

الحدث نمواً وتطوراً. وقد علق الدكتور أحمد هيكل على القصيدتين السابقتين بقوله إن الغزال قد اتجه إلى القص والحوار كأبياته في وصف الرحلة البحريـة، وما كان فيها مـن هيـاج للبحر ، وكبعض قطعـه التي صـور بها مـا كـان بينهـه وبين الإمبراطورة البيزنطية، ولم تكن طبيعة تلك الموضوعات المشتملة على أحداث هي التي فرضت على الشاعر هذا الاتجاه القصصي، وإنما كان اتجاه الشاعر وميله إلى طريقة القص، حتى في الموضوعات التي لا تفرض هذه الطريقة (rr).

وفي مشـه قصصسي رائع يدور بين الشـاعر وامرأة قد اشتراها، وخلع عليها مـن الصفات التزيينيـة كثيـراً، فهي بيضـاء ووجهها كالثـمس أو سـنا البدر ، ولكنها تعيسة، تنهمر دموعها وتفيض حسرة على مأساتها، فهي غير سعيدة مع الغزال الذي راح يقرعها ويعدد لها مظاهر ثرائه من مطعم وملبس وجوار ومكانة عظيمة، ولكنها رأت أن ذللك لا يحقق سعادتها (ع乏). 


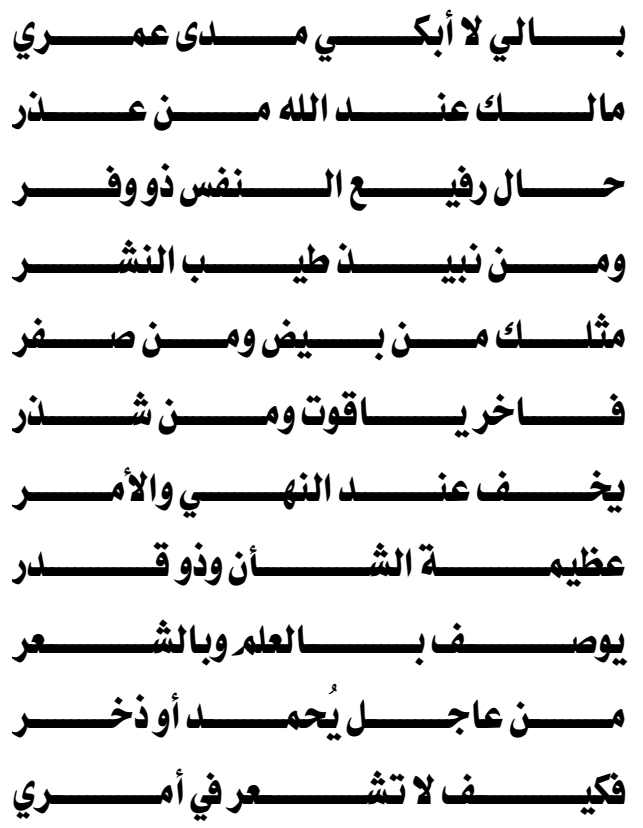

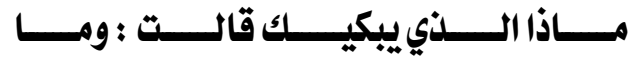
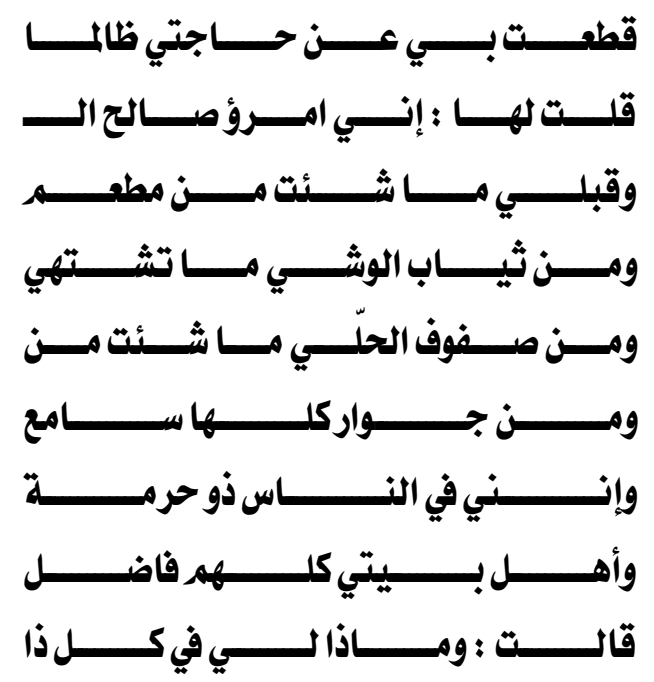

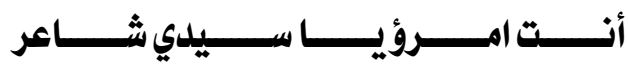

مـن الملاحظظ أن الصـفات التزينينيـة التي ذكرهـا الثـاعر قـد أعطـت بعـداً موضوعياً تمثل في الوظيفـة التعبيريـة، وهو في ذلك وصف " يهدف إلى تصسوير الشخصية وموضـعه أفعاله وبيان أسباب سلوكها وأفعالها عن طريق وصـف بيئة الشخصية ومكوناتها من الأشياء وكل ما يكون خلفيتها " (vo). ومن الملاحظ أيضاً أن هذا الوصف قد سـاعد الحـوار في تنميـة الأحداث، بالإضـافة إلى التحليل والتعليل اللذين بني عليهما الشاعر حواره القصصي بحيث أظهر الشاعر فشله في إقناع هذه المرأة التي عجز شاعرنا في مجاراتها.

ويميل الغزال في كثير من شعره القصصي إلى الوصف بأنواعه المختلفة، من تزيين وتوثيق وتفسير وغير ذلك ليصل الحدث من خلال ذلك إلى قمة التشويق في الفـن القصصس، فهذه امـرأة خلـع عليهـا الغـزال هذه المـرة صـفات منفرة ، فوصـفها بالصلع ونتوء العظام الذي يشبه ظهر الناقة التي برز عظمها حيث يقول ساخراء(بv): 


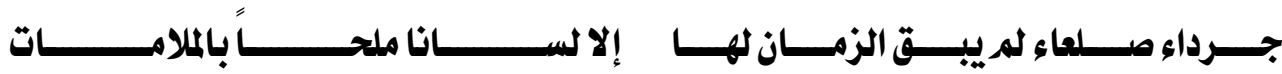

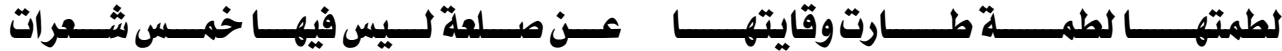

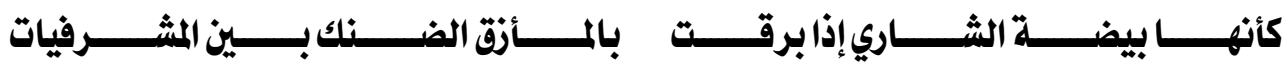

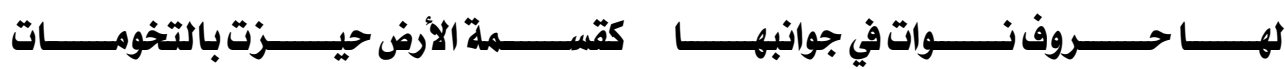

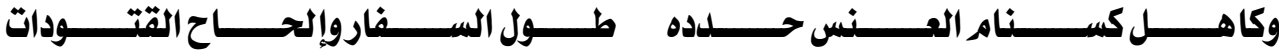

وفي مجال القصة الشعرية الخمرية نجد الغزال قد أجاد فيها هي الأخرى على

غرار الشاعر المشرقي الكبير أبي نواس، فرأيناه قد وصف حان الخمر، حيث وقف على بابه ونادي على الخمار فأقبل خفيف الروح قليل النوم، ودفع الغزال كل ملابسـه ثمنا للخمر واستعار من الخمار بدله يستتر بها (Vv)

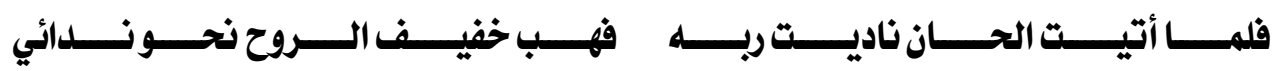

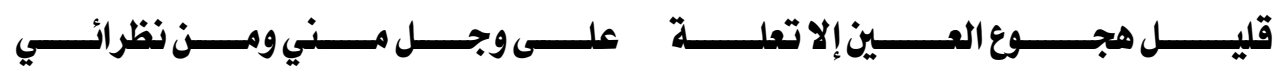

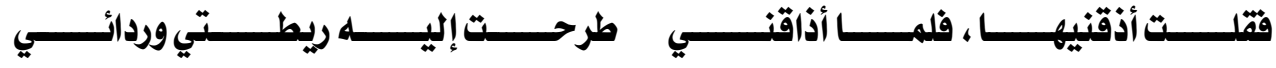

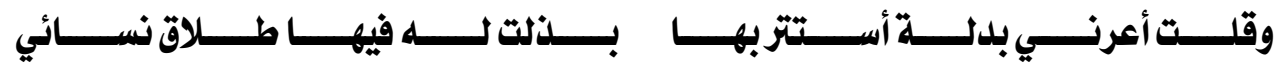

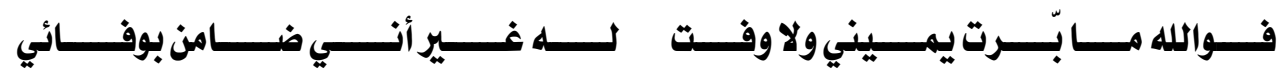

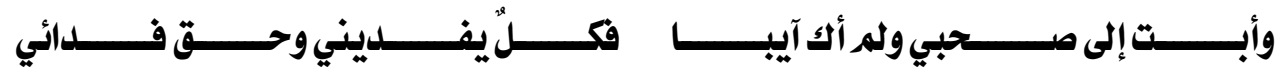

فهذه القصة الخمرية تذكرنا بخمرية أبي نواس " رحلة إلى حانوت خمار " وقد وصف فيها الغزال صـاحب الخمر عندما ناداه فهو خفيف الروح، وقليل النوم، وهذه الصفات المعنوية تدل على الاستعداد التام لصاحب الحان عند استقبال الزبائن، وقد ساعد هذا الوصف في تتمية أحداث القصة التي وصلت إلى قمتها عندما خلع الغزال ملابسـه وأعطاهـا لصـاحب الحـان مقابل الخمر ، وقد وصف الثـاعر حـال أصـابه عندما عاد إليهم بما يشتهونه من خمر بأنهم جميعاً فداء له. ولعل هذا المشهد القصصي الرائع الذي ساقه الغزال محاكاة وتناصاً عن أبي نواس يظهر لنـا براعـة الغزال في استخدام أسلوب السرد القصصـي، وخاصَّة إحدى 
وسائله وهي الوصف الذي جعل القارئ والمتلقي وكأنه يعايش المشهذ بكل تفاصيله،

وهذه هي الإجادة نفسها.

وهكذا، نهض الوصف كوسيلة من وسائل السرد القصصي بالحدث للوصول

إلى قمة التشويق، وجاءت مقطعات الغزال الوصفية تتبض بالحركة والحياة مما أدى دهى إلى خدمة السرد والتعرف على الثخصية والوصول بالحدث إلى ذروته. 


\section{خاتقة البحث}

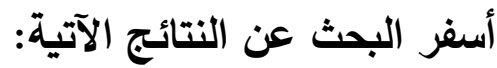

• يعد يحيى الغزال أول شعراء الأندلس عناية بالجانب القصصي في شعره.

• عبر الغزال في كثير من شعره القصصي عن قضايا ومواقف حدثت في عصره،

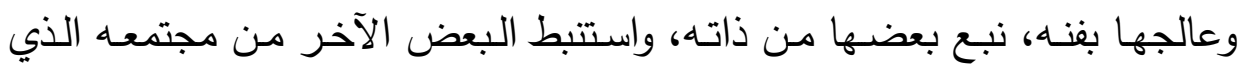
يعيش فيه، وقد برع في تجسيدها عن واقع ملموس ومعيش. • جاءت معظم أحداث قصص الغزال الثعرية في مشاهد حكائية بسيطة، وخاصـة

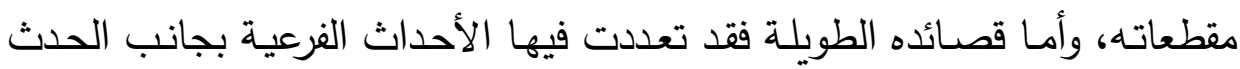

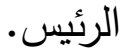

تمتع الغزال بالظرف والسخرية والدعابة ممـا عكس هذه الصفات على مشـاهده الحكائية، وأحداث قصصسه الشعرية، فجاءت مجسدة - في كثير من الأحيان -

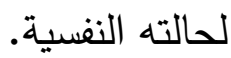
• تميزت قصص الغزال الثعرية بدقة التفاصيل وحيوية الأحداث والترقب والتشوق

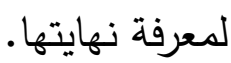
• لعب الغزال في كثير من قصصـه دور البطولة، وقلمـا ترك ذللك، ومن ثم فهو السارد لكثير من أحداث قصصه، والمحاور فيها. • تتوعت شخصيات الغزال ما بين العنصر النسائي والعنصر الرجالي، وإن غلب العنائ

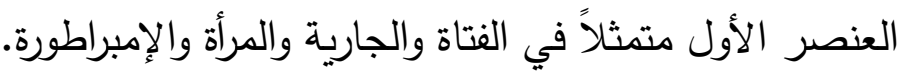

• عكست شخصيات الغزال بعض الظواهر الموجودة في مجتمعه الذي يعيش فيه. • لـم يقتصر الغزال في قصصـه على الشخصية الآدميـة، وإندـا تعداها إلى عـالم

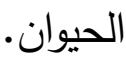


• شكل الحوار عنصراً مهماً من عناصر السرد القصصي عند الغزال، ومن ثم فهو

بنية رئيسة في شعره.

• تميز الحوار عند الغزال بالسهولة والبساطة والرشاقة وعدم التكلف والإسهام في تسلسل الحدث أو تحريكه.

• أكثر الغزال في حواره من فعل القول الذي يقوم عليه الحدث، وأحياناً أخرى يلجأ

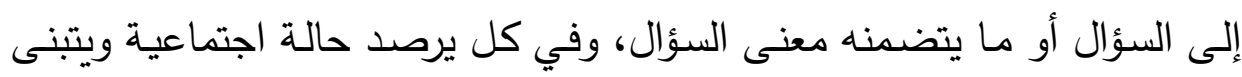
موقفاً منها.

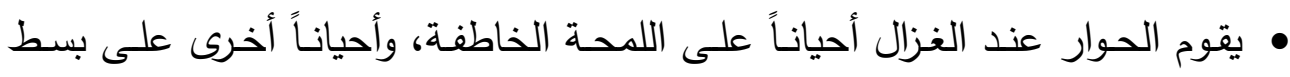
الحدث تصويرا للموقف أو المشهد الحكائي. • لجأ الغزال في بعض شعره إلى السرد الوصفي للأحداث والثخصيات التي جعلها تنطق بما يلائم الموقف. • ـــوّع الغـزال في سـرده الوصـفي بـين الوصـف التزيينـي والوصـف التـوثيقي أو

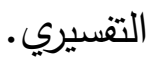
• جاءت لغة الغزال في السرد والحوار سهلة وبسيطة وشعبية في كثير من الأحيان. • قلت الصورة الثعرية في شعر الغزال القصصي، ومـع ذلك جاءت بعض الصور متآزرة مع الحوار حتى لكأنها جزء منه. 


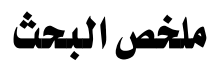

رصد هذا البحث ظـاهرة مهمة في شعر يحيى بن حكم الغزال وهي السرد

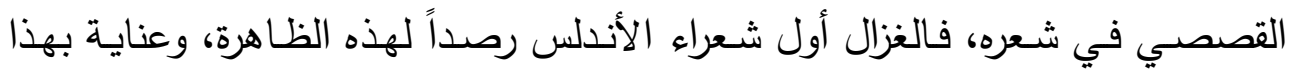
الجانب، وقد سلك هذا الطريق من خلال توظيف معطيات الواقع المعيش بكل ما فيه من مشاهد ومواقف تتبعث من وجدانه تارة ومن مجتمعه تارة أخرى.

ولم يكتف الغزال برصد هذه الظاهرة في شعره وإنما ربطها بظروف حياته

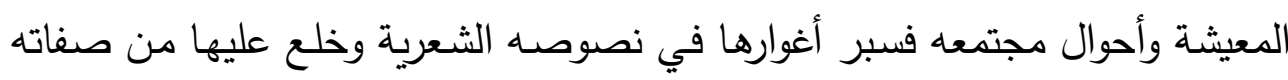

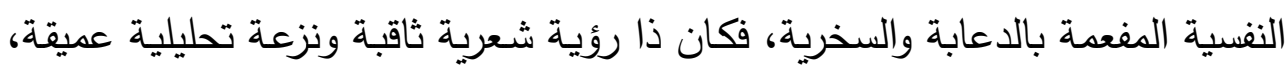
ولذا فقد تحدثا عن السرد القصصي في شعره وعناصره كالحدث والثخصية ووسائله

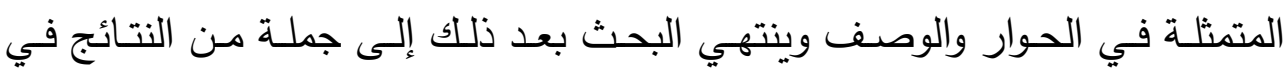

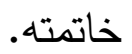


1- البنداق : يحيي بن الحكم الغزال، ص Vـ .

ץ- انظر : د/ إحسـان عباس، تاريخ الأدب الأندلسي، عصر سيادة قرطبة ص

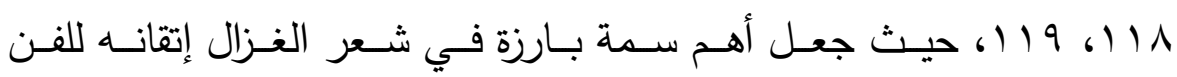
القصصي. ود/سعد شلبي : الأصول الفنية للشعر الأندلسي ص سمب، حيث قدمه على امرئ القيس وعمر بن أبي ربيعة في هذا الفن. ود/ على الغريب : شعر يحيي بن حكم الغزال، جمع وتحقيق ودراسة.

ץ- - د/ حميد لحمداني : بنية النص السردي من منظور النص الأدبي، ص 0ء. ع- جيرار جين:طرائق تحليل السرد الأدبي،ص با وانظرأيضا،سعيد يقطين:

$$
\begin{aligned}
& \text { الكلام والخبر " مقدمة للسرد العربي" ص گr } \\
& \text { - جينت : طرائق تحليل السرد الأدبي ،ص. V } \\
& \text { T- ينظر :حمد مفتاح : دينامية النص ،ص }
\end{aligned}
$$

V- عبد الله إبراهيم : التمثيل السردي في روايات الكوني ،صبr ^- عبد الملك مرتاض: في نظرية الرواية ، بحث في تقنيات السرد، صن V 9- جيرار جينت : خطاب الحكاية، ترجمة محمد معتصم وعبد الجليل الأزدي وعمر

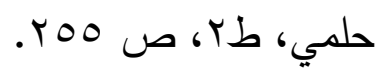

• ا-عبد القادر بن سـالم : مكونات السرد في النص القصصي الجزائري الجديد،

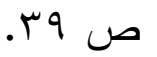

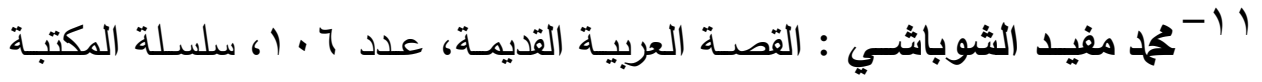

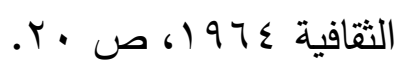


Y ا-تثارلتون : فنون الأدب، ترجمة نجيب محمود، ص ^ ا .

"ז سـعيد الوكيـل : تحليل النص السردي (( معارج ابن عربي نموذجاً ))، ص

ع ا-حميد لحمداني : بنية النص السردي، ط ب . . ץ، ص اب.

ا-تودروف : مقولات السرد الأدبي، ترجمة الحسين سحبان وفؤاد وصفا، ضمن

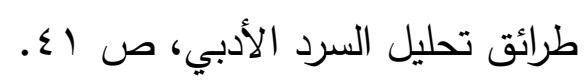

T1-حميد لحمداني : بنية النص السردي صراب

V ا-سعيد الوكيل: تحليل النص السردي(معارج ابن عربي نموذجا)ص. 1

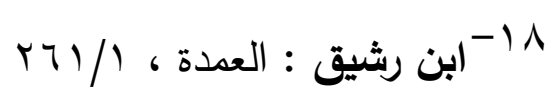

9 ا-انتصار جويد عبدان : البنية السردية في شعر نزار قباني، رسالة ماجستير،

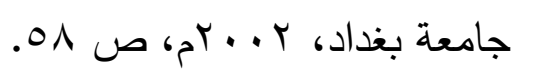

• ץ-د/ علي الغريب :شعر يحي بن الحكم الغزال، رقمبس.

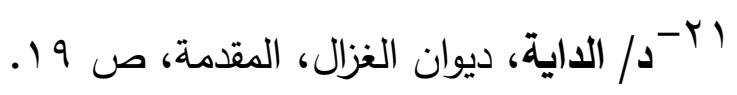

r r-د · يمنى العبد: تقنيات السرد الروائي ،ص ra

rr-د/ على الغريب : شعر يحيي بن حكم الغزال، رقمء؟.

$$
\begin{aligned}
& \text { گ ז-السابق : رقحما . } \\
& \text { هץ- السابق : رقم . . . } \\
& \text { דr-السابق : رقم } 00 . \\
& \text { السابق : رقم ه }
\end{aligned}
$$


^ץ- ابن سعيد: المغرب في حلى المغرب ، تحقيق د/ شوقي ضيف ، صلVO

q ج-د/ علي الغريب : شعر يحيى بن حكم الغزال رقمه.

• r-د/ على الغريب : شعر يحيي بن حكم الغزال،رقم

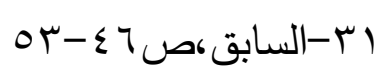

rr-ابـن المعتز : طبقات الشعراء، تحقيق عبد الستار فراج ، ص . وس، حيث القصيدة كاملة.

سب-د / علي الغريب : شعر يحيى بن حكم الغزال رقم جـ. وانظر القصـة كاملة في

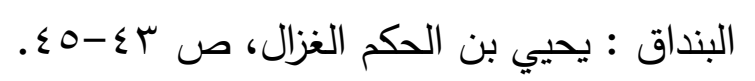

عَ-رولان بارت : مدخل إلى التحليل البنيوي للقصص، ترجمة منذر عياش، طا

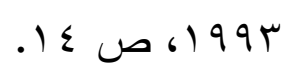

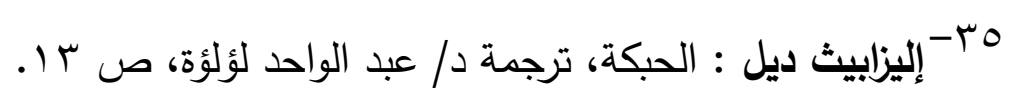

דr-د/ عفاف عبد المعطي : السرد بين الرواية المصرية والأمريكية ، ص V9 Y.

V" فورستر : أركان القصة، ترجمة كمال عياد، دار الكرنك، ص سا . وينظر :

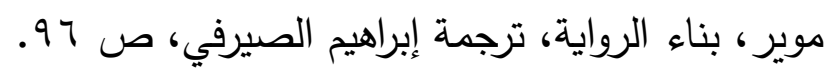

^ץ-|نتصار عبدان : البنية السردية في شعر نزار قباني، ص ل V.

$$
\text { q"-د/ علي الغريب: شعر يحيى بن حكم الغزال رقمهـ. }
$$

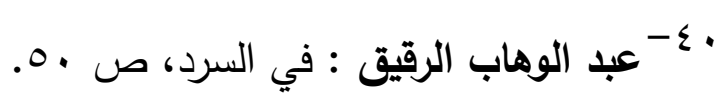

اء-د/علي الغريب : شعر يحيى بن حكم الغزال رقمهץ.

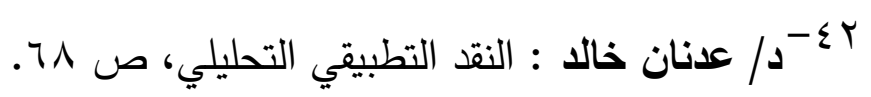

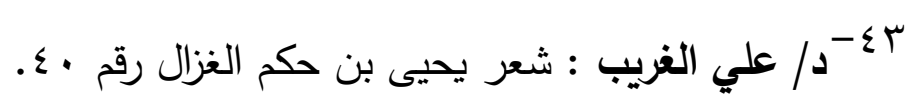




$$
\begin{aligned}
& \text { ــ - السابق : رقم } 9 . \\
& \text { 0ـ السابق : رقم } 0 . \\
& \text { Tـ السابق : رقم OV. } \\
& \text { - V } \\
& \text { ^ـ السابق : رقم ع V. } \\
& \text { 9 -السابق : رقم } 9 \text { ـ. } \\
& \text { •- السابق : رقم ^ء. }
\end{aligned}
$$

10

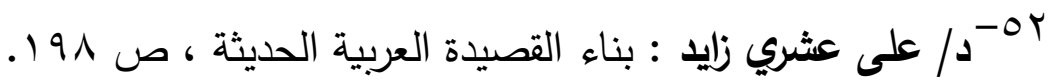
به-ميشـال عاصسي : الفن والأدب (بحث في الجماليات والأنواع الأدبية) ، ص .119

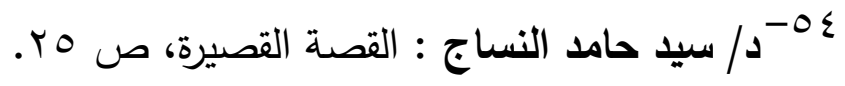

00-1/ علي الغريب : شعر يحيى بن حكم الغزال رقم سم .

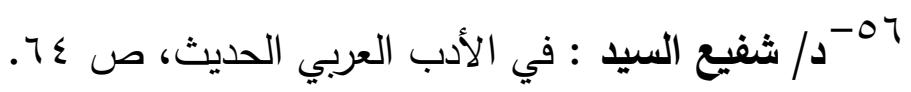

جيرار جينت : خطاب الحكاية، ص AN

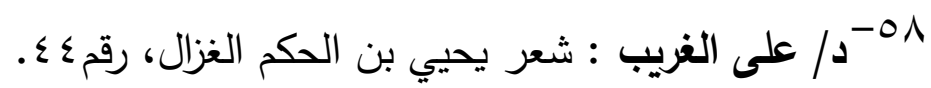

$$
\begin{aligned}
& \text { 9- السابق : رقم . r. } \\
& \text { • - السابق : رقمبا . } \\
& \text { آ-السابق : رقم هץ. }
\end{aligned}
$$




$$
\begin{aligned}
& \text { rا- السابق : رقم. } \\
& \text { זד- السابق : رقم } 07 . \\
& \text { ـ آلسابق : رقم . ع. } \\
& \text { 17- السابق: رقم } 9 .
\end{aligned}
$$

7 لآ-ألان روب: نحو رواية جديدة، ترجمة مصطفى إبراهيم ، صهم.

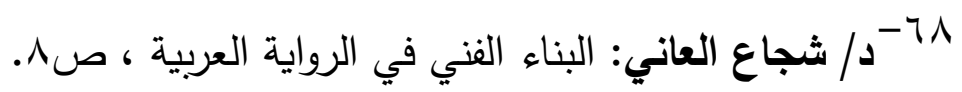
97-د/ عبد الملك مرتاض: في نظرية الرواية، ص. . .؟. • V-د/ علي الغريب: شعر يحيى بن حكم الغزال رقم ؟ه.

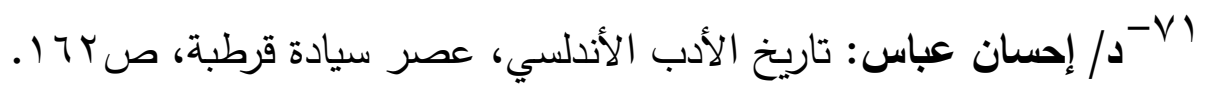

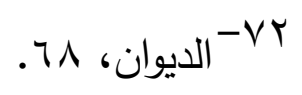

r

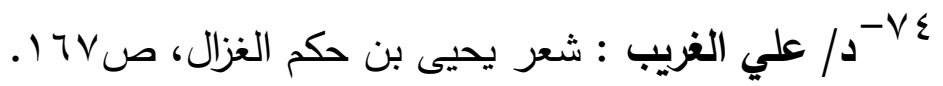

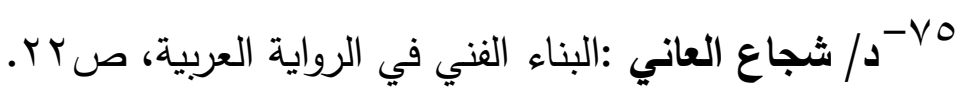

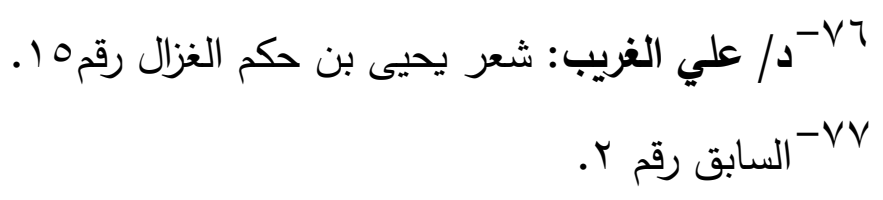




\section{المصادروالمراجع}

\section{أولاً: المصسادر}

ا. ابن حيان: المقتبس من أنباء أهل الأندلس، تحقيق محمود علي مكي، دار

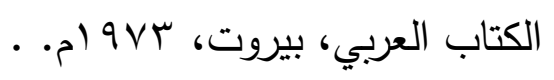

r. ابن دحيـة الكلبي: المطرب من أثعار أهل المغرب، تحقيق إبراهيم الإبياري

وحامد عبد المجيد وأحمد بدوي، وراجعه طه حسين، المطبعة الأميرية ؟ 190 1.

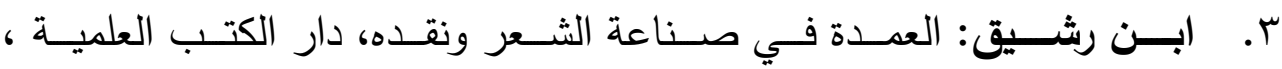

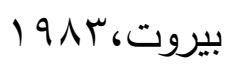

ـ. ابن سعيد المغربي: المغرب في حلى المغرب، الطبعة الثالثة، تحقيق شوقي

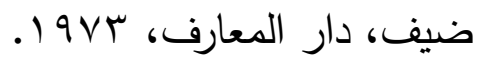

ه. ابن عبد ربه: العقد الفريد، الجزء الثالث، تحقيق أحمد أمين ومن معه، سلسلة

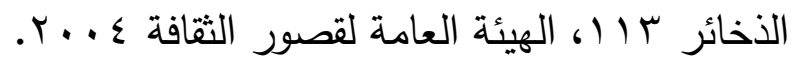

ז. ابن عذاري: البيان المغرب في أخبار الأندلس والمغرب، الجزء الثاني، تحقيق

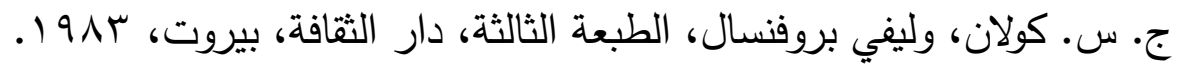
V. ابـن المعتز : طبقات الثـعراء، تحقيق عبد الستار فراج، الطبعة الرابعة، دار

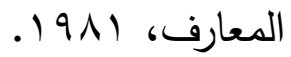

^. الثعالبي: يتيمة الدهر ، الجزء الثاني، تحقيق مفيد قميحة، الطبعة الأولى، دار

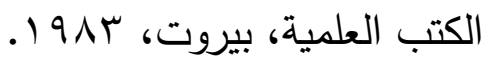

9. الحميــي: جذوة المقتبس في ذكـر ولاة الأنـلس، الـدار المصـرية للتـأليف

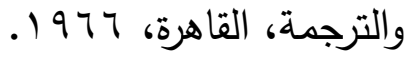


• 1. الخثــي: قضـاة قرطبـة، الـدار المصـرية للتـأليف والترجمـة والنشـر، القـاهرة،

ا ا. المقري التلمسـاني: نفح الطيب، تحقيق إحسـان عباس، دار صـادر، بيروت، .1911

ז ا. شـعر يحيسى بـن حكم الغزال، علـي الغريـب الشـناوي: جمع وتوثيق ودراسـة،

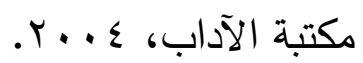

با ا. يحيى بن حكم الغزال: ديوان الغزال ، تحقيق ححم رضوان الداية، الطبعة الأولى، دار الفكر المعاصر ، بيروت، بهو 99 ـ.

\section{ثانياً: المراجع العربية}

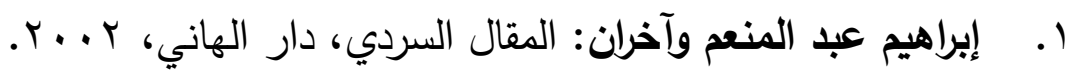

r. إحسان عباس: تاريخ الأدب الأندلسي، عصر سيادة قرطبة، الطبعة السـابعة،

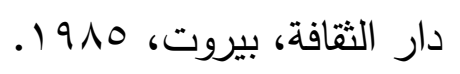

r. أحمد هيكل: الأدب الأندلسـي من الفتح إلى سقوط الخلافة، الطبعة العاشرة،

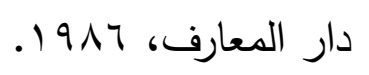

ع. بلدوي عثمان: بناء الثخصية الرئيسية، دار الحداثة، بيروت، 919 ـ . ه. حكمـة علي الأوسـي: فصسول في الأدب الأندلسي في القرنين الثاني والثالث

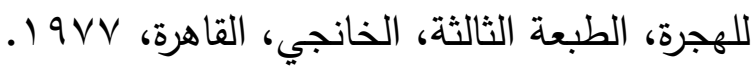
7 7. حلمي بدير: نظرية الأدب، دار عامر بالمنصورة، 1999. V. ميد لحمداني: بنية النص السردي (من منظور النص الأدبي) المركز الثقافي

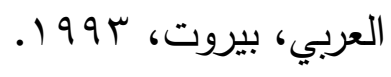


1. ســد شـلبي: الأصــول الفنيـة للشـعر الأندلسـي، عصـر الإمـارة، دار نهضــة

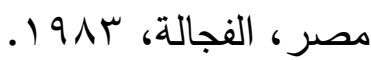

9. سـعيد الوكيـل: تحليل النص السـردي " معـارج ابـن عربي نموذجـاً "، الهيئة

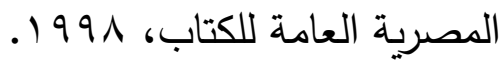

• ا. . سـعيد يقطين: الكلام والخبر " مقدمة للسرد العربي "، المركز الثقافي العربي،

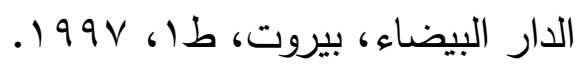

ا1 . سيد حامد النساج: القصة القصيرة، دار المعارف، د. ط، د. ت. r ا. شـاع العـاني: البنـاء الفني في الروايـة العربية، دار الثـئون الثقافيـة العامـة، بغداد، ع99 19.

r ا. شفيع السيد: قراءة في الأدب العربي الحديث، مكتبة الآداب، ؟ . . . ع ا. ـ شـوقي ضـيف: عصـر الـدول والإمـارات في الأندلس، الطبعـة الثانيـة، دار المعارف، ك 199

1 . . عبد الكريم الخطيب: القصص القرآني في مفهومه ومنطوقه، بيروت، د. ت. 7 ا. عبد القـادر بن سـالم: مكونـات السرد في النص القصصي الجزائري الجديد، منشورات اتحاد كتاب العرب، دمشق، 1 . . ب . V I . عبد اللطيف محفوظ: وظيفة الوصف في الروايـة، الدار البيضـاء، المغرب، م) 919 b

1 ا. عبد الملك مرتاض: في نظريـة الرواية، بحث في تقنيات السرد، عالم المعرفة

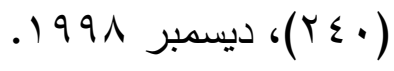
9 1 . عبد الوهاب الرقيق: في السرد، تونس، طا، 991 ـ.

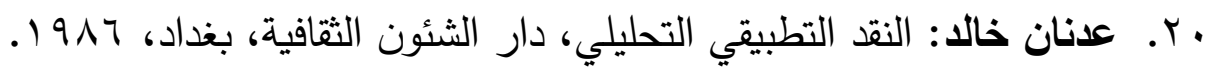


ا ا. . عفاف عبد المعطي: السرد بين الرواية المصرية والأمريكية، دراسـة في واقعية

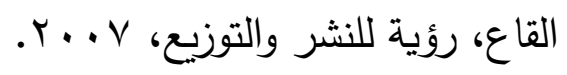

r.r. علي عشري زايد: بناء القصيدة العربية الحديثة، مكتبة الآداب، ^ . . . بr. علـي محمد ســلامة: الأدب العربـي في الأنـلس، الـدار العربيـة للموسـوعات،

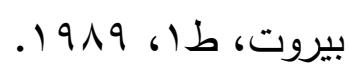

گ ז. كمال أبو ديب: الرؤى المقنعة (نحو منهج بنيوي في دراسـة الشعر الجاهلي)،

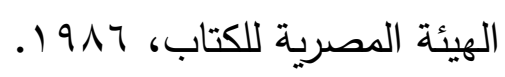

هr. محم رشيد ثابت : البنية القصصية ومدلولها الاجتماعي في حديث عيسى بن

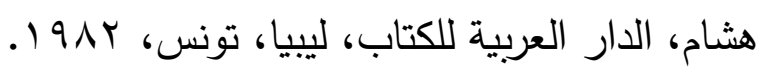

جr. ححم زكريا عناني: تاريخ الأدب الأندلسي، دار المعرفة الجامعية، الإسكندرية. rV . تحمه صالح البنداق: يحيى بن حكم الغزال، دار الآفاق الجديدة، بيروت، طا، $.19 \vee 9$

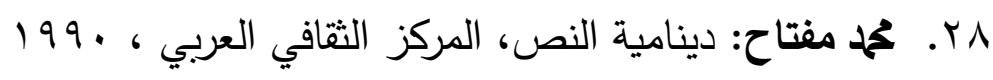
وץ. ميثـال عاصــي: الفـن والأدب (بحث في الجماليـات والأنـواع الأدبيـة)، دار

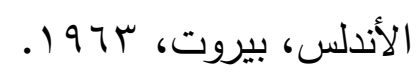

• ب. ــوري حمـودي القيسـي: لمحسات مـن الثـعر القصصسي في الأدب العربـي، منشورات دار الجاحظ، وزارة الثقافة، بغداد، ـ919 ا. اس. يمني العيد: تقنيات السرد الروائي (في ضوء المنهج البنيوي)، دار الفارابي،

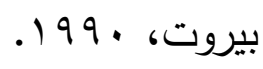

\section{ثالثاً : المراجع الأجنبية المترجمة}


ا. آلان روب: نحو رواية جديدة، ترجمة مصطفى إبراهيم، دار المعارف، مصر، د.ت.

r. إليزابث ديل: الحبكة، ترجمة عبد الواحد لؤلؤة، موسوعة المصطلح النقدي، وزارة

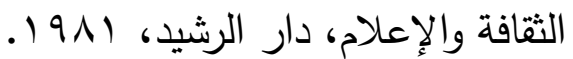

r. برناردي نوتو: عالم القصة، ترجمة ححم مصطفى هدارة، مؤسسة فرانكلين، القاهرة،

$$
\text { بيروت، } 979 \text { 1. }
$$

ع. تشـارلتون: فــون الأدب، ترجمـة زكي نجيـب محمـود، لجنـة التأليف والترجمـة،

القاهرة.

هـ تودروف: مقولات السرد الأدبي، ترجمة الحسين سحبان وفؤاد صفا، ضمن طرائق

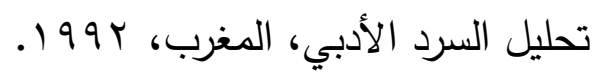

7. تـودروف وجينـت طرائق تحليل السـرد الأدبـي، ترجمـة مجموعـة مـن الباحثين،

$$
\text { منشورات اتحاد كتاب المغرب، } 999 \text { 1. }
$$

V. جيـرار جينت خطـاب الحكايـة، ترجمـة خحمد معتصـم وعبد الجليل الأزدي وعمر

$$
\text { الحلي، الهيئة العامة للمطابع الأميرية، و99 19. }
$$

^. رولان بـارت: التحليل البنيوي للسرد، ضمن طرائق تحليل السرد الأدبي، ترجمـة

$$
\text { حسن بحراوي وآخرين. }
$$

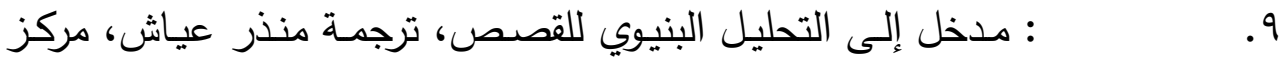

$$
\text { الإنماء الحضاري، حلب، س99 19. }
$$

\section{رابعاً: الدوريـات}

ا ـ أسـامة اختيـار : بنيـة المشـه الحكائي في شعر يحيى بـ حكم الغزال، مجلـة

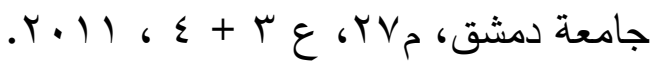


r. جيرار جينت: مقال بعنوان " حدود السرد "، ترجمة بنعيسى بوحمالة، مجلة آفاق

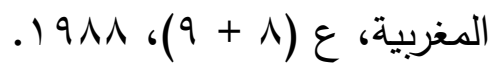

r. عبد الحميد زايد: الرمز والأسطورة الفرعونية، مجلة عالم الفكر ، عَ، 910 ا. ع. عبد الله إبراهيم: التمثيل السردي في روايات الكوني ، مجلة علامـات ،جدة ،

$$
1999 / T_{r}
$$

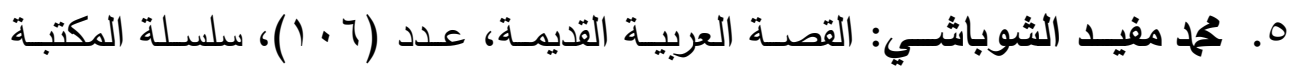
الثقافية، ع 9 ا ـ.

\section{خامساً: الرسائل الجامعية}

انتصـار جويد عبدان: البنية السردية في شعر نزار قباني، رسالة ماجستير، جامعة

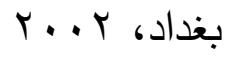

